SECCIÓN ABIERTA 

REVISTA DE DERECHO UNED, NÚM. 18, 2016

\title{
ESPECIALIDADES DEL PROCESO DE DESAHUCIO POR FALTA DE PAGO DESDE UN PUNTO DE VISTA DOCTRINAL Y JURISPRUDENCIAL
}

\author{
SPECIALTIES OF THE PROCESS OF EVICTION \\ FOR NON-PAYMENT FROM A DOCTRINAL \\ AND JURISPRUDENTIAL POINT OF VIEW
}

\section{Marina Martín GonZÁlez}

Máster EEES Procura UNED

Resumen: El Proceso de Desahucio por Falta de Pago se configura actualmente en la Ley de Enjuiciamiento Civil como una especialidad del Juicio Verbal, cuya nota característica principal es el empleo de la técnica monitoria. Se trata de un proceso sumario en el que el arrendador, fundado en el impago de rentas, pretende la recuperación de la posesión real de la finca y, además, en caso de acumulación de acciones, la reclamación de su pago. En este trabajo haremos una revisión crítica de este proceso desde un punto de vista crítico, atendiendo, especialmente, a aquellas cuestiones que suscitan un debate doctrinal y jurisprudencial.

Abstract: The Process of Eviction for Non-Payment is actually defined by the Civil Procedure Rules as a verbal hearing legal specialty, which stands out because of the use of the admonitory technique. It is a summary process on which the lessor, based on repeated non-payments, aims to get back the real possession of the estate and, additionally, in the event of accumulation of several legal actions, reclaim payment for these. This paper aims to analyze this process from a critical perspective, paying special attention to the most complex matters from the point of view of jurisprudence and legal doctrine.

Palabras clave: Desahucio, Juicio Verbal, Técnica Monitoria, Cantidades Debidas, Especialidades. 
Keywords: Eviction, Verbal Hearing, Admonitory Technique, Amounts Due, Specialties.

Recepción original: 18/02/2016

Aceptación original: 6/04/2016

Sumario: I. Planteamiento y panorámica general; II. Cuestiones generales del proceso de desahucio por falta de pago: 1. La Conveniencia de la Técnica Monitoria en el Proceso de Desahucio; 2. El objeto del Proceso de Desahucio por Falta de Pago: A. Acción principal: Recuperación de la posesión real de la finca; B. Acción acumulada de reclamación de rentas debidas; 3. Legitimación Procesal: A. Legitimación Activa. B. Legitimación Pasiva; 4. La Enervación del Desahucio. III. Elementos procedimentales del proceso de desahucio por falta de pago: 1. La Demanda: A. ¿Demanda sucinta o demanda ordinaria? Cambios introducidos por la Ley 42/2015, de 5 de octubre, de reforma de la Ley de Enjuiciamiento Civil; B. La cuantía del proceso; C. El pago de la Tasa Judicial; 2. Régimen de Notificaciones; 3. El Requerimiento de Pago: Posibles conductas del demandado; 4. La condena en costas; 5 . Especialidades en materia de recursos; 6. La Ejecución del Desahucio: El lanzamiento; IV. Conclusiones; V. Bibliografía; VII. Índice de resoluciones judiciales citadas.

\section{PLANTEAMIENTO Y PANORÁMICA GENERAL}

Hemos de concebir el actual Proceso de Desahucio por Falta de Pago como fruto de las numerosas reformas legislativas en materia procesal civil que han tenido lugar desde la aprobación de la Ley 1/2000, de 7 de enero, de Enjuiciamiento Civil.

En principio, con esta nueva Ley se buscaba la progresiva desaparición de los llamados «Procesos Especiales» por medio de la regulación de todos los procesos bajo criterios unificadores y en un único texto legal ${ }^{1}$. De este modo, rompiendo con la antigua LEC de 1881, el Juicio de Desahucio dejó de estar regulado en un Título independiente como proceso especial, para pasar a convertirse en una especialidad procesal del Juicio Verbal (Artículo 250.1.1. ${ }^{\circ}$ LEC).

${ }^{1}$ Vid. OBÓN DÍAZ, A., «Regulación actual del proceso de desahucio: Especial referencia al desahucio por falta de pago como juicio rápido y sumario», Noticias Jurídicas, Marzo de 2004, pág. 1. Así como, FERNÁNDEZ GIL, C., El desahucio "exprés» por falta de pago. Legislación, comentarios y formularios, 2. ${ }^{a}$ Edición, Madrid, 2013, [Versión digital] pág. 13. IBARRA SÁNCHEZ, J. L., Teoría y práctica de los juicios verbales de desahucio. El juicio monitorio de desahucio por falta de pago, 2. ${ }^{a}$ Edición, Madrid, 2013, pág. 100. 
No obstante, pese a este intento simplificador y unificador de procedimientos, las sucesivas reformas procesales que han incidido directamente en el Proceso de Desahucio por Falta de Pago nos llevan a seguir concibiéndolo como un verdadero proceso especial ${ }^{2}$ pues las numerosas especialidades que se han ido introduciendo con respecto a las normas generales del Juicio Verbal, prácticamente, pasan a otorgarle autonomía propia.

En la actualidad, se trata de un proceso de gran relevancia en la práctica forense pues, constituye el cauce a través del cual el arrendador ejercita su derecho fundamental a la tutela judicial efectiva reconocido en el artículo 24 de nuestra Constitución, ante una situación de impago de renta o cantidad asimilada. En concreto, a través del mismo se pretende la tutela sumaria del derecho posesorio del titular del inmueble ante un incumplimiento contractual.

Precisamente, como consecuencia de esa trascendencia práctica y, por verse implicados en su regulación, además, factores económicos como el fomento del mercado del alquiler, el Juicio de Desahucio por Falta de Pago se ha visto afectado por numerosas y sustanciales reformas legislativas tendentes a su agilización y, sobre todo, a la reducción de trámites. Se ha buscado, a lo largo de más de una década, que el arrendador recupere la plena confianza en la Administración de Justicia para la resolución de conflictos. Para ello, se refuerza la protección jurídica del actor en esta clase de procedimientos, procurando, además, la celeridad en su resolución.

El objeto del presente estudio es ofrecer un análisis sobre la regulación actual de este proceso, enriquecido con las aportaciones de la doctrina y la Jurisprudencia más relevantes.

\section{CUESTIONES GENERALES DEL PROCESO DE DESAHUCIO POR FALTA DE PAGO}

\section{La Conveniencia de la Técnica Monitoria en el Proceso de Desahucio}

Desde la entrada en vigor de la Ley 1/2000, de 7 de enero, de Enjuiciamiento Civil, el legislador ha impulsado mediante sucesivas re-

${ }^{2}$ IBARRA SÁNCHEZ, J. L., Teoría y práctica de los juicios verbales de desahucio. El juicio monitorio de desahucio por falta de pago, 2. ${ }^{a}$ Edición, Madrid, 2013, p. 100. Además, por remisión de esta primera obra destacamos: GARBERÍ LLOBREGAT, J., Los procesos civiles, Tomo II, Barcelona, 2001, p. 822; y RAMOS MÉNDEZ, F., Dere-

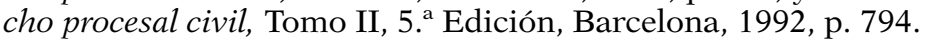


formas un proyecto de simplificación de trámites procedimentales y, en general, de agilización de la Administración de Justicia, que, como resultaba previsible, ha afectado al Proceso de Desahucio por Falta de Pago con el fin de convertirlo en un proceso verdaderamente sumario donde el arrendador vea satisfechas sus pretensiones con la menor dilación posible.

Mediante la Ley 37/2011, de 10 de octubre, de medidas de agilización procesal, se extendió la aplicación de la técnica monitoria al Proceso de Desahucio por Falta de Pago, dando lugar a los llamados «Desahucios Exprés».

La técnica monitoria, característica del Procedimiento Monitorio de Protección del Crédito, regulado en los artículos 812 a 818 de la LEC, comporta, en resumidos términos, que, tras la inicial aportación documental por el actor instando la tutela sumaria de su crédito, se efectúa al demandado un requerimiento de pago, ante el que o bien podrá abonar la cantidad reclamada, o bien cabe su oposición de modo que pase a resolverse el litigio por el cauce del juicio correspondiente. Por cuanto atañe a la ausencia de respuesta a dicho requerimiento, tras la correspondiente instancia del actor, procederá el despacho de ejecución ${ }^{3}$.

La elección de dicha técnica como medida de agilización procesal se deriva de la naturaleza ejecutiva propia del Proceso Monitorio Común, que garantiza una tutela sumaria del crédito. Con ello, el legislador opta por un cambio en la regulación vigente del Proceso de Desahucio por Falta de Pago, en el que también existe una reclamación de cantidades debidas ${ }^{4}$, tendente a lograr su aproximación al Proceso Monitorio Común, de modo que nuestro proceso quede dotado de una mayor sumariedad y simplicidad de trámites.

Esta reforma supuso una auténtica ruptura con el pasado para el Proceso de Desahucio por Falta de Pago y lo dotó de una nueva especialidad con respecto a las normas generales del Juicio Verbal.

${ }^{3} \mathrm{Vid}$. BONET NAVARRO, J., «La pluralidad subjetiva en los procesos civiles caracterizados por la llamada "técnica monitoria"», Revista Jurídica de Castilla y León, núm. 9, Mayo de 2006, págs. 98 y 99. Así como, CORTÉS DOMÍNGUEZ, V. y MORENO CATENA, V., Derecho Procesal Civil. Parte Especial, 7. ${ }^{a}$ Edición, Valencia, 2013, págs. 183 ss.

${ }^{4}$ Vid. GUDÍN RODRÍGUEZ-MAGARIÑOS, A. E., «La regulación del requerimiento previo en el juicio de desahucio tras la Ley de Medidas de Agilización Procesal», La Ley, núm. 17714/2011, 2011, pág. 1. 


\section{El objeto del Proceso de Desahucio por Falta de Pago}

A. Acción principal: Recuperación de la posesión real de la finca

El objeto del Proceso de Desahucio por Falta de Pago lo constituye, principalmente, la recuperación posesoria real de la finca urbana o rústica. Esto es, el dueño, usufructuario o persona con derecho a

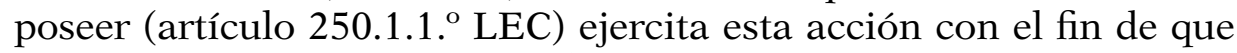
su dominio posesorio sobre la finca se restituya, tomando como fundamento el impago de rentas o cantidades asimiladas debidas, lo que supone un incumplimiento del contrato y causa de su resolución de acuerdo con el artículo 114 de la Ley 29/1994, de 24 de noviembre, de Arrendamientos Urbanos (en adelante LAU).

Otra definición muy clara y completa del objeto de la acción principal de desahucio por falta de pago nos la ofrece GARBERÍ LLOBREGAT, quien afirma que «el Juicio de Desahucio tiene por objeto enjuiciar el derecho del actor a resolver el contrato arrendaticio y desalojar al arrendatario sobre la base del incumplimiento, por parte de este último, de la obligación de satisfacer la renta y demás cantidades a que se encuentre obligado, de un lado; y el de éste a permanecer en la finca arrendada de otro (...). Su finalidad es la resolución de un arrendamiento y la recuperación posesoria a través de la desposesión del demandado, basada en una concreta causa resolutoria, a saber: La falta de pago de la renta o cantidades debidas por el arrendatario» 5 .

Ahora bien, existe un cierto debate, tanto doctrinal como jurisprudencial, en torno a la gravedad que debe revestir el impago de la renta para que pueda prosperar la acción de desahucio.

Sorprendentemente, desde la Sentencia del Tribunal Supremo de 24 de julio de $2008^{6}$, en la que se pretendía la unificación de las doctrinas jurisprudenciales de las Audiencias Provinciales, la opinión mayoritaria es la favorable a que el impago de una sola mensualidad o parte de ella, e incluso el mero retraso en el pago de la misma, pueda motivar el progreso de la acción de desahucio. Así, se declara como doctrina jurisprudencial «que el pago de la renta del arrendamiento, fuera de plazo y después de presentada la demanda de desahucio no excluye la aplicabilidad de la resolución arrendaticia, y ello aunque la demanda se funde en el impago de una sola mensualidad de renta, sin que el arrendador venga obligado a soportar que el arrendata-

${ }^{5}$ GARBERÍ LLOBREGAT, J., Los nuevos juicios verbales de desahucio en la Ley de Enjuiciamiento Civil, Barcelona, 2009, p. 48.

${ }^{6}$ STS 755/2008 (Sala de lo Civil, Sección 1. ${ }^{a}$ ), de 24 de julio de 2008, 2. ${ }^{\circ}$ Acuerdo del Fallo. 
rio se retrase de ordinario en el abono de las rentas periódicas», no constituyendo el ejercicio de la acción ningún abuso de derecho, ni requiriéndose actitud culposa o rebelde manifiesta por parte del arrendatario deudor para declarar el desahucio ${ }^{7}$.

En sentido contrario, cierto sector doctrinal formado, entre otros, por GUERRA PÉREZ y ACHÓN BRUÑÉN, entiende que «el desahucio por falta de pago por cantidad irrisoria no podría pretenderse, pues constituiría un abuso de derecho intentar desahuciar al arrendatario por cantidades insignificantes ${ }^{8}$. Siguiendo esta argumentación, con un impago de cantidades irrisorias se debería estar, pues, ante un mero retraso, y no ante un incumplimiento contractual que lleve aparejado como sanción la resolución definitiva del contrato. Desde esta concepción se critica, además, el poco margen de decisión y ponderación de circunstancias de que dispone el Juez a la hora de decidir sobre la resolución del contrato en estos casos con base en el principio de proporcionalidad 9 .

\section{B. Acción acumulada de reclamación de rentas debidas}

A partir de la reforma efectuada por la Ley 23/2003, de 10 de julio, de Garantías en la Venta de Bienes de Consumo, en su Disposición

${ }^{7}$ A favor, STS 180/2014, de 27 de marzo, la cual nos remite a la STS 1219/2008 (Sala de lo Civil, Sección. ${ }^{a}$ ), de 19 de diciembre. Fundamento Jurídico $2 .^{\circ}$ y $3 .^{\circ}$ : «(...) ello aunque dicha demanda se funde en el impago de una única mensualidad de renta y ésta haya sido satisfecha extemporáneamente. (...) La primera causa específica de resolución del artículo 114.1 LAU se refiere a la falta de pago de renta o de las cantidades que se le asimilan. (...) Por ser el contrato de arrendamiento urbano oneroso y conmutativo, es evidente que la primera obligación del arrendatario es la de pagar la renta; por otra parte, salvo cuando las partes hayan acordado que su abono se efectúe en un sólo momento, este contrato es de tracto sucesivo y el impago de una sola mensualidad puede motivar la resolución contractual». En este mismo sentido: SAP Alicante (Sección 5.a) núm. 375/2003, de 10 de septiembre; SSTS 193/2009, de 26 de marzo, y 684/2009, de 20 de octubre de 2009; SAP Islas Baleares (Sección 3. ${ }^{a}$ ) núm. 300/2010, de 20 de junio; SAP Barcelona (Sección 13. ${ }^{a}$ ) núm. 135/2011, de 28 de marzo; SAP Murcia (Sección 4. ${ }^{a}$ ) núm. 575/2011, de 17 de noviembre; SAP A Coruña (Sección 3.a ) núm. 370/2012, de 10 de junio; SAP Valladolid (Sección 1. a) núm. 267/2012, 15 de junio; SAP Barcelona (Sección 4. ${ }^{\text {a }}$ ) núm. 425/2012, de 19 de julio; SAP Islas Baleares (Sección 5. ${ }^{a}$ ) núm. 420/2012, de 4 de octubre; STS 137/2014, de 18 de marzo.

${ }^{8}$ ACHÓN BRUÑÉN, M. J., "Cantidades debidas que pueden dar lugar al juicio de desahucio», VLex, Id. VLEX-464637.

${ }^{9}$ Vid. ACHÓN BRUÑÉN, M. J., «Problemas prácticos derivados de la reforma del juicio de desahucio por falta de pago por la Ley de Medidas de Agilización Procesal», Diario La Ley, núm. 7738, Sección Tribuna, noviembre de 2011 [En línea]. Según afirma en su artículo, "de "lege data", estas circunstancias no pueden ni tan si quiera ser ponderadas por el Juzgador, el cual se ve compelido a dictar una sentencia de desahucio si el arrendatario no enerva ni tampoco prueba el pago de la renta». 
Final Tercera, y tras la derogación del antiguo artículo $40.2 \mathrm{LAU}^{10}$, es posible acumular a la acción de desahucio por falta de pago la acción de reclamación de rentas debidas, con independencia de su cuantía (artículo 438.3.3. ${ }^{\mathrm{a}}$ LEC).

En este caso, se produce la acumulación en único proceso de varias pretensiones ${ }^{11}$ (artículos 71 y siguientes LEC): la relativa al desalojo de la finca tendente a la devolución de la posesión real de la misma al actor con derecho de posesión sobre ella; y la dirigida al cobro de las cantidades adeudadas por el arrendatario. Posibilidad que obedece a razones de economía procesal y que, adicionalmente, favorece al actor, quien, en un único proceso, puede ver satisfechas la totalidad de sus pretensiones contra el arrendatario.

Con carácter previo a la reforma operada por la Ley 19/2009, de 23 de noviembre, -que incorporaba definitivamente la reclamación de rentas y cantidades debidas por el arrendatario en el ámbito Juicio Verbal por razón de materia-, se evitaba que el actor debiera ejercitar posteriormente otras acciones a través de Juicio Ordinario de acuerdo con la anterior dicción del artículo 249.1.6. ${ }^{\circ}$ LEC. Sin perjuicio de que, de conformidad con la redacción del artículo 818.2 LEC previa a la Ley 19/2009, tal acción pudiera tramitarse en Juicio Verbal en los litigios de cuantía inferior a 3.000 euros tras la incoación del pertinente Proceso Monitorio. Se evitaban, además, los problemas que pudiera acarrear la localización del arrendatario una vez desahuciado a la hora de reclamar la deuda ${ }^{12}$.

Cabe destacar que el conocimiento de la acción acumulada de reclamación de rentas tiene carácter plenario, por lo que, en lo que se refiere a tal pretensión, el demandado no se verá afectado por la limitación en cuanto a alegación y prueba del artículo 444.1 LEC, la cual sí que operaría con respecto a la pretensión de recuperación de la finca urbana o rústica dada en arrendamiento según el tenor literal de dicho precepto. Como consecuencia de ello, surge entonces una duda en torno a si verdaderamente este procedimiento, al

${ }^{10}$ Vid. CONTIJOCH PRATDESABA, R., «Posibilidad de la acumulación de las acciones de desahucio y de reclamación de rentas contra el arrendatario y los fiadores solidarios» Revista Profesional de Administradores de Fincas de Cataluña, núm. 69, Barcelona, Primer Trimestre, 2007, págs. 52 y 53.

${ }^{11}$ Vid. MONTERO AROCA, J., y FLORS MATÍES, J., Tratado de Juicio Verbal, 2. Edición, Navarra, 2004, pág. 651.

${ }^{12}$ ACHÓN BRUÑÉN, M. J., "Demanda del juicio de desahucio», VLex, Id. VLEX464619 , p. 5. MAGRO SERVET, V., «La regulación del juicio de desahucio en la Ley 1/2000, de 7 de enero, de Enjuiciamiento Civil». Revista Sepín. Arrendamientos Urbanos. N. ${ }^{\circ}$ 208-A. Noviembre 2000, p.27. 
que se le ha acumulado una pretensión plenaria, continúa siendo sumario.

Sobre esta cuestión encontramos un interesante debate doctrinal, por el momento sin solución, que podemos resumir básicamente en tres posturas principales ${ }^{13}$ : Una primera en favor de la diferenciación de la fuerza de cosa juzgada de los distintos pronunciamientos de la sentencia ${ }^{14}$. Una segunda contraria a la «desnaturalización» de la sumariedad del Proceso de Desahucio por Falta de Pago y, en consecuencia, defensora de extender el carácter sumario a todas las pretensiones ejercitadas «dado el carácter preponderante y principal del desahucio frente a la reclamación de rentas que vendría a ser accesoria, cualquiera que fuera su cuantía» ${ }^{15}$. Y, por último, una tercera posición defensora de una interpretación restrictiva del artículo 447.2 LEC, entendiendo que este precepto tan solo excluye de la fuerza juzgada, como afirma ÁLVAREZ SÁNCHEZ16, «a los procesos en los que la única pretensión sea la de resolución del contrato con el consiguiente lanzamiento del arrendatario». Fuera de estos casos, la sentencia en su totalidad tendría fuerza de cosa juzgada. A opinión de IBARRA SÁNCHEZ, pese a que en la práctica tiende a extenderse la sumariedad a todas las pretensiones, "convendría desterrar la absoluta ausencia de cosa juzgada material en estos juicios [de desahucio] y que tuvieran este efecto, aunque limitado en relación a su objeto» ${ }^{17}$.

${ }^{13}$ Conforme a la clasificación realizada por IBARRA SÁNCHEZ, J. L. Teoría y Práctica de los Juicios Verbales de Desahucio. El juicio monitorio de desahucio por falta de pago. 2. ${ }^{\text {a }}$ edición, Madrid, 2013, pp. 171 ss. Y tomando como referencia para nuestra exposición su obra.

${ }^{14}$ A favor: MONTERO AROCA, J., y FLORS MATÍES, J., Tratado de Juicio Verbal, 2. ${ }^{\circ}$ Edición, Navarra, 2004, p. 661. Así como, O'CALLAGAN MUÑOZ, X, VV. AA., Encuesta jurídica, "Acumulación de acciones de desahucio por falta de pago y reclamación de rentas. A la vista del artículo 447.2 LEC, ¿La Sentencia firma en cuanto a la reclamación económica no tiene efectos de cosa juzgada? En este caso, ¿Cuál sería el proceso posterior?», Revista Arrendamientos Urbanos, n. ${ }^{\circ}$ 218, Madrid, pp. 5 y 6. Jurisprudencia: SAP Barcelona (Sección 13. ${ }^{\text {) }}$ ), núm. 553/2008, de 14 de octubre, F. J. 2. ${ }^{\circ}$; y SAP Zaragoza (Sección 4. ${ }^{\text {) }}$ ), núm. 489/2010, de 5 de noviembre de 2010.

${ }^{15}$ CREMADES MORANT, J., VV. AA.: Encuesta Jurídica, «Acumulación de acciones de desahucio por falta de pago y reclamación de rentas. A la vista del artículo 447.2 LEC, ¿La Sentencia firma en cuanto a la reclamación económica no tiene efectos de cosa juzgada? En este caso, ¿Cuál sería el proceso posterior?», Revista Arrendamientos Urbanos Sepín, n. ${ }^{\circ}$ 218, Octubre de 2002, Las Rozas, Madrid, pág. 5.

${ }^{16}$ ÁLVAREZ SÁNCHEZ, J. I., VV. AA.: Encuesta Jurídica, «Acumulación de acciones de desahucio por falta de pago y reclamación de rentas. A la vista del artículo 447.2 LEC, ¿La Sentencia firma en cuanto a la reclamación económica no tiene efectos de cosa juzgada? En este caso, ¿Cuál sería el proceso posterior?», Revista Arrendamientos Urbanos Sepín, n. ${ }^{\circ}$ 218, Octubre de 2002, Las Rozas (Madrid), pág. 6.

${ }^{17}$ IBARRA SÁNCHEZ, J. L., op. cit., pág.175. 


\section{La legitimación procesal}

Fundándose en el artículo 10 LEC, las partes procesalmente legitimadas, tanto activa como pasivamente, son los respectivos titulares de la relación jurídica sobre la que verse el objeto del proceso. En concreto, en el Proceso de Desahucio por Falta de Pago, de conformidad con lo dispuesto en el artículo 250.1.1. ${ }^{\circ}$ LEC en relación con la legitimación activa, será «dueño, usufructuario ${ }^{18}$ o cualquier persona con derecho a poseer». Nada se dice, por el contrario, sobre la legitimación pasiva, que entendemos que recaerá sobre quien, efectivamente, posea en régimen de alquiler la finca urbana o rústica y sea deudor del pago de las rentas o cantidades debidas semejantes en que se funde el proceso de desahucio.

A continuación, siguiendo el esquema que nos ofrece FERNÁNDEZ GIL ${ }^{19}$, analizaremos los supuestos de legitimación procesal que nos han resultado más interesantes y a los que no se refiere expresamente la LEC vigente.

\section{A. Legitimación activa en el Proceso de Desahucio}

a. Comunidad de Bienes: Existencia de dos o más copropietarios arrendadores

En estos casos nos encontramos ante el hecho de que la finca rústica o urbana arrendada pertenece pro indiviso a varias personas (arts. 392 CC y sigs.).

$\mathrm{Al}$ respecto, es amplia la Jurisprudencia que ofrece una solución a favor de que uno de los comuneros, en beneficio de la comunidad, pueda ejercitar acciones en nombre de la misma, ya sea para ejercitar derechos de la comunidad o para defenderlos, "con la consecuencia de que la Sentencia dictada a su favor aprovecha a los demás sin que le perjudique la contraria ${ }^{20}$, no siendo necesario que la demanda vaya firmada por el resto de comuneros.

${ }^{18}$ Vid. SEOANE SPIEGELBERG, J. L., «Algunas cuestiones puntales de legitimación en los procesos arrendaticios urbanos: Su tratamiento en la LEC 2000», Repositorio de la Universidade Da Coruña, Universidade Da Coruña, A Coruña, 2002, pág. 969. Jurisprudencia menor: SAP Murcia (Sección 5. ${ }^{a}$ ), n. ${ }^{\circ}$ 147/2000, de 9 de octubre; SAP Alicante (Sección 5. ${ }^{\mathrm{a}}$ ), n. ${ }^{\mathrm{o}}$ 378/2009, de 2 de diciembre; SAP Alicante (Sección 5. ${ }^{\text {) }}$, n. ${ }^{\circ}$ 70/2010, de 18 de febrero; SAP Madrid (Sección 19. ${ }^{a}$ ), n. ${ }^{\circ}$ 631/2012, de 19 de diciembre; SAP Madrid (Sección 10. ${ }^{\mathrm{a}}$ ), n. ${ }^{\circ}$ 131/2012, de 15 de febrero.

${ }^{19}$ FERNÁNDEZ GIL, C., op. cit., págs. 54 ss.

${ }^{20}$ STS (Sala de lo Civil, Sección Unica), núm. 364/2003, de 10 de abril, F. J. 3. ${ }^{\circ}$ A favor: STS (Sala de lo Civil), de 8 de julio de 1997, F. J.1. ${ }^{\circ}$ 
Si bien, junto con el requisito de actuar en provecho común, se precisa que no exista desacuerdo entre los comuneros sobre el asunto en concreto. En tal sentido, para que el comunero en cuestión esté legitimado activamente para ejercitar la acción, ninguno de los demás comuneros habrá podido manifestar, ya sea expresa o tácitamente, su disconformidad con dicha actuación ${ }^{21}$. En tal caso, con base en lo que dispone el artículo 398 C. C, deberá adoptarse un acuerdo por mayoría de «los partícipes que representen la mayor cantidad de intereses que constituyan objeto de la comunidad», pudiendo acudirse a los Tribunales ante una imposibilidad de acuerdo.

\section{b. Situación del cónyuge no arrendador}

Constante matrimonio, si uno de los cónyuges suscribe un contrato de arrendamiento sin intervención del otro, puede surgirnos la duda de si, existiendo un régimen económico matrimonial ganancial, el cónyuge no titular del contrato goza también de legitimación activa para ejercitar una acción de desahucio por falta de pago. En este caso, nos encontramos ante una numerosa y clara jurisprudencia.

Tomando como fundamento el artículo 1.257 del C. C., en virtud del cual «los contratos sólo producen efectos entre las partes que los otorgan y sus herederos (...)», la Jurisprudencia se pronuncia en contra de la legitimación activa del cónyuge no titular de la relación contractual arrendaticia para ejercitar una acción de resolución de la misma, y afirma que esta legitimación corresponde, en exclusiva, al cónyuge titular del contrato, con razón de la naturaleza personal del contrato de arrendamiento y con independencia del régimen económico matrimonial vigente pues, como ha afirmado el Tribunal Supremo, la situación contractual del cónyuge arrendador no forma parte de la comunidad de bienes gananciales ${ }^{22}$. Cosa dis-

${ }^{21}$ En este sentido se pronuncian: STS (Sala de lo Civil), núm. 26/2000, de 20 de enero; SAP Almería (Sección 3.a), núm. 29/2005, de 18 de febrero; SAP Cádiz (Sala 1. ${ }^{\mathrm{a}}$ ), núm. 59/2005, de 15 de abril; SAP Las Palmas (Sección 3. ${ }^{\text {) }}$, núm. 3/2006, de 11 de enero; SAP Murcia (Sección 5. ${ }^{\text {}}$ ), núm. 426/2012, de 27 de noviembre, F. J. 3. ${ }^{\circ}$

${ }^{22}$ STS (Sala de lo Civil, Sección 1. ${ }^{\text {) }}$, núm. 220/2009, de 3 de abril, F. J. 6. ${ }^{\circ}$ : «os contratos producen efectos entre las partes contratantes y sus herederos, y por ello las posiciones contractuales de cada uno de los cónyuges en los contratos de arrendamiento que hayan concluido no forman parte de la sociedad de gananciales, porque, además, se trata de derechos personales». Además, STS (Sala de lo Civil) núm. 247/2013, de 22 de abril, F. J. 2. ${ }^{\circ}$; SAP (Sección 14. ${ }^{\text {a }}$ ) Madrid, núm. 368/2013, de 21 de octubre; SSTS (Sala de lo Civil, Sección 1. ${ }^{a}$ ), núm. 206/2011, de 22 de marzo, y núm. 343/2012, de 30 de mayo. Así como el Acuerdo de Unificación de Criterios del Orden Civil de la Audiencia Provincial de Madrid, de octubre de 2011, p. 28: "1. ${ }^{\circ}$ Si constante el matrimonio uno de los cónyuges suscribe un contrato de arrenda- 
tinta sería que ambos cónyuges firmaran el contrato arrendaticio, supuesto en el que actuarían como cotitulares de la relación jurídica, siéndoles aplicables las normas expuestas anteriormente para los comuneros ${ }^{23}$.

\section{c. Legitimación activa del heredero}

Nuevamente, con base en el artículo 1.257 C. C, así como en el artículo $659 \mathrm{C}$. C, conforme al cual la herencia comprenderá «todos los bienes, derechos y obligaciones de una persona que no se extingan por su muerte», podemos entender que, tras la muerte del arrendador, la relación arrendaticia, junto con los derechos y obligaciones que de ella se derivan, pervivirán, quedando el heredero subrogado en la posición jurídica del causante ${ }^{24}$.

En la Ley 29/1994, de 24 de noviembre, de Arrendamientos Urbanos, tan solo se prevé la extinción del contrato por muerte del arrendatario en los términos previstos en los artículos 16 y 33 LAU. Ninguna referencia se hace, por tanto, a la muerte del arrendador como causa de extinción del contrato, salvo cuando el derecho del arrendador se derive de un derecho de usufructo, caso en que sí que se prevé en el artículo 13.2 LAU la resolución del derecho del arrendador, lo que resulta lógico pues el usufructo es personal y se extingue con la muerte, por lo que no formará parte de la herencia (art. 513 C. C) ${ }^{25}$. Por último, cabe señalar que, de existir dos o más herederos, se aplicarán las disposiciones previstas para el condominio ${ }^{26}$.

\section{d. Situación procesal del adquirente de la finca arrendada}

La Ley no deja lugar a dudas sobre la legitimación activa para ejercitar la acción de desahucio por falta de pago del adquirente de la finca urbana o rústica arrendada pues, este nuevo adquirente pasa a tener un derecho de propiedad sobre la misma. Sobre ello dispo-

miento de vivienda, sólo él ostentará la titularidad arrendaticia y será el sujeto de derechos y obligaciones frente al arrendador, cualquiera que sea el régimen económico matrimonial».

${ }^{23}$ STS 208/1994, de 14 de marzo: Compraventa por mitad e iguales partes pro indiviso de cónyuges con régimen económico matrimonial de separación de bienes.

${ }^{24}$ Vid. PINTÓ RUÍZ, J. J., «Responsabilidad de los herederos», Noticias Jurídicas, Noviembre de 2005, p.1.

${ }^{25}$ El mismo planteamiento encontramos en la Ley 49/2003, de 26 de noviembre, de Arrendamientos Rústicos, en concreto, en su artículo 24.

${ }^{26}$ STS (Sala de lo Civil), núm. 465/2000, de 11 de mayo. 
nen los artículos 14 y 29 de la Ley de Arrendamientos Urbanos y el artículo 22 de la Ley de Arrendamientos Rústicos que el adquirente de una finca arrendada «quedará subrogado en los derechos y obligaciones del arrendador», en los términos que establezca cada precepto legal ${ }^{27}$.

No obstante, el conflicto sobreviene al acumular a la acción de reclamación de rentas debidas a la acción de desahucio por falta de pago.

En favor de que el nuevo adquirente pueda reclamar las rentas vencidas y debidas con anterioridad a la adquisición de la finca, la SAP Valladolid, de 16 de julio de 2004, que defiende en sus Fundamentos Jurídicos $3 .^{\circ}$ y $4 .^{\circ}$ que, a falta de pacto expreso entre las partes contratantes de reserva del derecho de crédito sobre las rentas debidas hasta el momento de la compraventa, la subrogación que se produce en derechos y obligaciones posee «carácter absoluto».

Por el contrario, en favor del mantenimiento del derecho de crédito del primer arrendador cabe destacar la SAP Madrid, de 8 de marzo de 2000. En ella se dispone que los efectos de la subrogación se producen desde el momento de la adquisición, a excepción de que en el momento de la transmisión de la finca se realizase un pacto a favor de la transmisión de ese derecho de crédito, caso en el que el adquirente sí sucedería al primitivo arrendador en su posición de acreedor de las rentas anteriormente vencidas y no pagadas. Añade, además, que habrá que notificar al arrendatario dicha cesión de modo que tuviera conocimiento de su nuevo acreedor.

\section{e. Legitimación activa del administrador}

La Jurisprudencia reconoce que el arrendamiento es un acto de administración ${ }^{28}$, por lo que, puede afirmarse que «quien está facultado para arrendar, lo debe estar para ejercitar la acción de desahucio ${ }^{29}$.

${ }^{27}$ Vid. FERNÁNDEZ GIL, C., op. cit., pág. 59. Jurisprudencia: SAP Madrid (Sección 18. ${ }^{\text {a) }}$, de 8 de marzo del 2000; SAP Valladolid (Sección 1. ${ }^{a}$ ), núm. 245/2004, de 16 de julio; SAP Cádiz (Sección 2. ${ }^{a}$ ), núm. 158/2008, de 22 de abril.

${ }^{28}$ SAP Jaén (Sección 2. ${ }^{\mathrm{a}}$ ), núm. 227/2012, de 25 de septiembre, F. J.2. ${ }^{\circ}$; STS (Sala de lo Civil), núm. 331/1999, de 24 de abril.

${ }^{29}$ SAP Málaga (Sección 6. ${ }^{\text {a }}$, núm. 464/2000, de 21 de junio. A favor: SAP Málaga (Sección 6. ${ }^{\mathrm{a}}$ ), núm. 848/2002, de 22 de noviembre, F. J.1. ${ }^{\circ}$; SAP Baleares (Sección 3. ${ }^{\mathrm{a}}$ ), núm. 423/2004, de 7 de octubre. 
B. La legitimación pasiva en el Proceso de Desahucio por Falta de Pago

Como afirmábamos, nada dice la LEC en particular sobre la legitimación pasiva en esta clase de procesos, es por ello que, atendiendo a los arts. 10 LEC y 1.257 C. C., el legitimado pasivamente será el titular del contrato de arrendamiento contra el que el otro titular se dirija fundado en un incumplimiento contractual. A continuación trataremos el supuesto cuyo estudio nos ha resultado más interesante.

\section{a. Legitimación pasiva constante matrimonio}

La legitimación pasiva en los procesos de desahucio por falta de pago, en consonancia con lo que expusimos en el epígrafe anterior, corresponde en exclusiva al cónyuge titular del contrato.

Una muestra clara de lo anterior consta en la LAU, donde figuran numerosas referencias a la diferencia existente entre el "cónyuge arrendatario» y el "cónyuge no arrendatario» (arts. 12, 15, 16 LAU). Es más, como sostiene ACHÓN BRUÑÉN, «si ambos cónyuges debieran considerarse titulares del contrato locaticio no tendría sentido que la LAU contemplara la subrogación del cónyuge en la relación arrendaticia en caso de muerte del arrendatario" ${ }^{30}$ [art. 16.1.a) LAU].

Resultará, en exclusiva, cuando ambos cónyuges sean titulares del contrato arrendaticio, la aplicación las normas propias de la comunidad de bienes: ambos deberán ser demandados conjuntamente, al carecer dicha comunidad de personalidad jurídica propia y ostentar los dos la legitimación pasiva ${ }^{31}$.

En cuanto al cónyuge no arrendatario cabe cuestionarse, en el supuesto de acumulación de la acción de reclamación de rentas debidas a la acción de desahucio, la posible afectación de los bienes integrantes de la sociedad de gananciales al pago de dichas rentas, o la responsabilidad subsidiaria de este cónyuge en virtud de los artículos 1.318 y 1.319 C. C. Y es que, como afirma FERNÁNDEZ GIL ${ }^{32}$, desde el momento en que se arrienda un inmueble con el fin de destinarlo a

${ }^{30}$ ACHÓN BRUÑÉN, M. J., «Problemas relativos a la legitimación en el juicio de desahucio», VLex, Id. VLEX-464616, pág. 4. A favor: SAP Cáceres (Sección 1.a), núm. 153/2002, de 27 de junio; SAP Sevilla (Sección 6. ${ }^{\text {) }}$, núm. 142/2009, de 30 de marzo.

${ }^{31}$ Según han manifestado la SAP Guadalajara, núm. 75/2002, de 27 de febrero; y la SAP Vizcaya (Sección 5. ${ }^{\mathrm{a}}$ ), núm. 56/2006, de 2 de febrero, F. J. 2. ${ }^{\circ}$; tomando como referencia las SSTS de 22 de mayo de 1993; de 16 de febrero de 1998, de 17 de noviembre de 1977 y de 28 de julio de 1999.

${ }^{32}$ Vid. FERNÁNDEZ GIL, C., op. cit. pág. 73. 
vivienda familiar, las rentas pasan solidariamente a estar a cargo del caudal familiar pues, se trata de gastos destinados al sostenimiento de las cargas familiares. Si bien, el hecho de que de algún modo este cónyuge pueda ver afectado su propio patrimonio no nos lleva a afirmar su legitimación pasiva en el proceso ${ }^{33}$, sin perjuicio de que, en relación a la reclamación de rentas, deba notificársele, en su caso, la ejecución del embargo, en los términos del artículo 144 del Reglamento Hipotecario. Igualmente, de acuerdo con el artículo 1.318 del Código Civil, de no disponer el cónyuge litigante de los recursos económicos suficientes para sufragar los costes del proceso, éstos irán también a cargo del caudal común.

Por otro lado, cuando el uso de la vivienda familiar le sea atribuido al cónyuge no titular, tampoco se verá afectada la legitimación pasiva. El cónyuge que hubiere celebrado el contrato de arrendamiento inicialmente continuará en la misma posición jurídica tras esta atribución ${ }^{34}$, sin perjuicio de que algún sector doctrinal ${ }^{35}$ defienda en estas circunstancias la legitimación pasiva del cónyuge que posee efectivamente la vivienda. En todo caso, el cónyuge no titular tendrá la posibilidad de intervenir en el proceso en los términos establecidos en el artículo 13 LEC $^{36}$.

\section{La enervación del desahucio}

Con base en el artículo 22.4 LEC, podemos definir la enervación del desahucio como la facultad que tiene el arrendatario de poner fin al Proceso de Desahucio por Falta de Pago con anterioridad a la celebración de la Vista, por medio del pago o la consignación judicial o

${ }^{33}$ Tal y como dispone la SAP Alicante (Sección 5. a), núm. 104/2012, de 8 de marzo, en su Fundamento Jurídico 3. ${ }^{\circ}$, «una cosa es que exista un determinado régimen económico matrimonial y una responsabilidad más o menos extensa de bienes gananciales, y una muy distinta que lo realizado por uno solo de los cónyuges haya de considerarse efectuado por ambos como si se estuviera en presencia de un único sujeto (...), sin perjuicio de que en caso de haberse efectuado la acumulación a la acción de desahucio la de reclamación de rentas debidas, puedan embargarse bienes gananciales en el proceso de ejecución dirigido contra uno solo de los cónyuges». A favor: SAP Asturias (Sección 4. ${ }^{\text {) }}$, núm. 231/2001, de 10 de mayo.

${ }^{34}$ STC (Sala Primera) 289/1993, de 4 de octubre, SAP Jaén (Sección 2. ${ }^{\text {a) }}$, núm. 135/2004, de 2 de junio; SAP Córdoba (Sección 2. ${ }^{a}$ ), de 19 de diciembre del 2000.

${ }^{35}$ LOSCERTALES FUERTES, D., «La adjudicación judicial del uso de la vivienda familiar por separación o divorcio de uno de los cónyuges y sus diferentes situaciones.» Revista Sepín, Arrendamientos Urbanos, Núm. 229, octubre de 2002, pág.14. A favor: SAP Ourense (Sección 2. ${ }^{a}$ ), núm. 116/2002, de 22 de marzo.

${ }^{36}$ SAP Vizcaya (Sección 5.a), núm. 763/2000, de 6 de septiembre; SAP Madrid (Sección 14. ${ }^{\mathrm{a}}$ ), núm. 9/2003, de 23 de diciembre. 
notarial de las cantidades reclamadas en la demanda, junto con las debidas en el momento del pago enervador ${ }^{37}$.

Verdaderamente, no podemos considerarlo un derecho propio del arrendador. Más bien, siguiendo la doctrina mayoritaria del Tribunal Supremo, constituye una "oportunidad» que el legislador otorga al arrendatario ante unas determinadas circunstancias económicas y sociales para frenar el desahucio ${ }^{38}$. Dicho en palabras de MARTÍN CONTRERAS, "nos encontramos con un supuesto de desactivación legal ${ }^{39}$ del Proceso de Desahucio por Falta de Pago. Se trata, pues, de una forma de terminación anticipada del proceso autónoma y propia del proceso de desahucio de finca urbana o rústica por falta de pago ${ }^{40}$, que sólo operará una vez y siempre que el arrendador no hubiese requerido de pago de un modo fehaciente al arrendatario, al menos, con una antelación de treinta días a la presentación de la demanda.

No obstante, cabe destacar que la doctrina mayoritaria ${ }^{41}$ considera que nos encontramos ante una facultad personal, por lo que, en el caso de cambio de la persona del arrendatario dentro de un mismo contrato por cesión, este nuevo titular podrá hacer uso de la enervación, con independencia de que su antecesor ya hubiera recurrido a la misma. Tal y como dispone la Sentencia de la AP de Huelva, de 27 de noviembre de 2007, «aunque la cesión implica una sustitución personal en el mismo contrato, existen facetas de la relación que forzosamente varian para adaptarse a la nueva configuración personal (...).» Si

${ }^{37}$ SAP Murcia (Sección 3. a), núm. 52/2005, de 24 d febrero; SAP La Rioja (Sección 1. ${ }^{\text {a }}$ ), núm. 79/2005, de 18 de marzo; SAP Castellón (Sección 1.a), núm. 125/2005, de 30 de junio; Auto AP Murcia (Sección 3. ${ }^{a}$ ), núm. 76/2005, de 1 de julio, entre otras.

${ }^{38} \mathrm{Al}$ respecto, la STS 193/2009, de 26 de marzo, expone: "Que configurar la enervación como un derecho pugna con un derecho del arrendador tan esencial como es recibir el precio del arrendamiento, derecho éste correlativo a la obligación igualmente esencial del arrendatario de pagarlo (artículos 1.543, 1.546 y 1.555.1. ${ }^{\circ}$ C. C.), de suerte que la enervación se presenta no tanto como un derecho cuanto como una oportunidad del arrendatario de evitar el desahucio, legalmente configurada en cada momento histórico atendiendo a razones sociales. (...)». Así como la STS (Sala de lo Civil, Sección $\left.1 .^{\mathrm{a}}\right)$, núm. 684/2009, de 20 de octubre, que en su Fundamento Jurídico 2. ${ }^{\circ}$ dispone: «la enervación del desahucio no puede entenderse como un "derecho procesal» que menoscabe el derecho sustantivo del arrendatario a que se le pague la renta puntualmente, sino como una oportunidad que la propia Ley administra (...).»

${ }^{39}$ MARTÍN CONTRERAS, L., "La enervación», Revista Arrendamientos Urbanos Sepín, núm. 246, abril, 2004, Pozuelo de Alarcón (Madrid).

${ }^{40}$ SAP Pontevedra, núm. 158/2012, de 29 de marzo, F. J. 3. ${ }^{\circ}$ y 4. . $^{\circ}$ SAP Baleares (Sección 3. a), núm. 213/2003, de 3 de abril; SAP Barcelona (Sección 13. ${ }^{a}$ ), núm. 652/2004, de 30 de septiembre.

${ }^{41}$ Vid. Entre otros, GARBERÍ LLOBREGAT, J., Los nuevos juicios verbales de desahucio en la Ley de Enjuiciamiento Civil, Barcelona, 2009, p. 92; IBARRA SÁNCHEZ, J. L. op. cit., pág. 372 . 
bien, no se trata de una cuestión pacífica pues encontramos algunas Sentencias en contra del carácter personal de la facultad de enervación ${ }^{42}$.

En relación a la notificación de la posibilidad de hacer uso de la enervación, con anterioridad a la Ley 37/2011, de 10 de octubre, de medidas de agilización procesal, la facultad de enervación de la acción de desahucio se notificaba al arrendatario por medio de una cédula de citación. Tras esa reforma, esta notificación se realiza en el mismo requerimiento de pago que dicte el Letrado de la Administración de Justicia tras la admisión de la demanda y con carácter previo a la vista. En dicho requerimiento, de acuerdo con los artículos 440.3 y 22.4 LEC, se informará al demandado de que dispone de un plazo de diez días para que, de pretender la enervación, pague o ponga a disposición del Juez o Notario las cantidades adeudadas.

Por otro lado, existía cierta problemática en cuanto al momento procesal en que procedía la enervación del desahucio. Con anterioridad a la Ley de medidas de agilización procesal, se podía enervar la acción de desahucio hasta justo antes de la celebración de la Vista (art. 440.3 LEC). Sin embargo, con esta reforma se estableció otro momento preclusivo: Diez días desde la notificación del requerimiento de pago del Letrado de la Administración de Justicia (art. 22 LEC).

Con anterioridad a la Ley 4/2013, de 4 de junio, de medidas de flexibilización y fomento del mercado de alquiler de viviendas, que modificó el artículo 22.4 LEC, del análisis de los artículos 22 y 440.3 LEC parecía desprenderse que se podía enervar la acción "previamente a la celebración de la Vista» (art. 22 LEC) o "en el plazo de diez días» desde el requerimiento, esto es, se podía llegar a entender que el legislador había señalado dos momentos para la enervación.

Sin embargo, teniendo en cuenta el espíritu y finalidad de la Ley, que no era otro que la agilización procesal, se debía entender que legislador no estableció dos momentos para enervar la acción sino que, más bien, aunque el artículo 22.4 LEC señalaba el momento de la enervación con anterioridad a la Vista, era en el artículo 440.2 LEC donde encontramos la concreción del plazo de que dispone el demandado para enervar ${ }^{43}$. Afortunadamente, como hemos señalado, esta cuestión quedó resuelta con Ley 4/2013, de 4 de junio.

${ }^{42}$ En contra del carácter personal de la facultad de enervación encontramos: SAP Asturias (Sección 4. ${ }^{\text {) }}$, núm. 365/2002, de 9 de julio; SAP Alicante (Sección 5. ${ }^{\text {) }}$, núm. 377/2006, de 26 de octubre.

${ }^{43}$ En este sentido se pronunció en su momento la SAP La Rioja (Sección 1. a), núm. 136/2013, de 15 de abril, F. J.3. ${ }^{\circ}$ : «(...) existen dudas acerca de si el artículo 22.4 
Otra cuestión controvertida es que el pago sea realizado con posterioridad a la admisión de la demanda, pero con carácter previo al requerimiento del Letrado de la Administración de Justicia.

Es cierto que muchos autores se inclinan a opinar que todo pago realizado desde el momento de presentación de la demanda, por efecto de la litispendencia, ha de tener efecto enervador del desahucio ${ }^{44}$. No obstante, cabría cuestionarse qué sentido tiene, pues, que el legislador haya determinado el plazo de enervación en diez días desde la notificación del requerimiento de pago $^{45}$. En este sentido se ha pronunciado recientemente el Tribunal Supremo en su Sentencia de 24 de marzo de $2014^{46}$, en la que dispuso que «el pago de la renta del arrendamiento de vivienda fuera de plazo y después de presentada la demanda de desahucio no excluye la resolución del contrato, y esto aunque la demanda se funde en el impago de una sola mensualidad de renta». Y es que, como hemos dicho, la enervación no es un derecho, sino una oportunidad que ofrece el legislador al arrendatario que ha de ejercitarse en sus determinados términos.

\section{ELEMENTOS PROCEDIMENTALES DEL PROCESO DE DESAHUCIO POR FALTA DE PAGO}

\section{La demanda}

A. ¿Demanda sucinta o demanda ordinaria?

Tomando como referencia la definición elaborada por IBARRA SÁNCHEZ, la demanda constituye el vehículo procesal formal a través del cual se inicia un proceso civil. En palabras de este mismo autor, podemos añadir que se trata de «un acto de parte de iniciación procesal mediante el que se solicita del órgano jurisdiccional una deter-

de la LEC permite un mayor plazo de enervación, hasta antes de la celebración de la vista. Sin embargo, de la conjunción de los artículos 22.4 y 440.3 de la LEC no resulta que se hayan establecido dos momentos para enervar la acción, pues aunque el artículo 22.4 LEC incluye la expresión "previamente a la celebración de la vista", no se puede considerar de forma aislada, porque va unida a la expresión "en los términos previstos en el artículo 440.3 de esta Ley».»

${ }^{44}$ Vid. TRIGO SIERRA, E., y PÉREZ-PUJAZÓN MILLÁN, M. E., «Cuestiones Procesales Prácticas Relativas al Juicio de Desahucio por impago de Rentas», Actualidad Jurídica Uría Méndez. Núm. 15-2006, 2006, pág. 55.

${ }^{45}$ IBARRA SÁNCHEZ, J. L., op. cit., pág. 391.

${ }^{46}$ STS núm. 180/2014, de 27 de marzo, RJ 2014\1530. Junto con ella podemos destacar: SAP Baleares (Sección 3. ${ }^{\text {) }}$, núm. 174/2007, de 7 de mayo. 
minada tutela jurídica ${ }^{47}$. Estamos ante un elemento esencial en el proceso toda vez que, a través de él, el actor ejercita su derecho fundamental a la tutela judicial efectiva previsto y reconocido en el artículo $24 \mathrm{CE}$.

En cuanto a la demanda en sí, al constituir el procedimiento una especialidad del Juicio Verbal, si con anterioridad a la reciente reforma de la LEC introducida por la Ley 42/2015, de 5 de octubre, el Proceso de Desahucio por Falta de Pago se iniciaba mediante demanda sucinta, en la actualidad se ha extendido el uso de la demanda ordinaria al Juicio Verbal. Con todo, y a la vista de su reducido contenido, así como la falta de necesidad de integrar en ella fundamentación fáctica o jurídica, fue objeto de dura crítica doctrinal.

$\mathrm{Al}$ carecer de fundamentación, un sector estimaba que este tipo de demanda no contenía una pretensión completa en sentido técnicojurídico. Como afirmaba IBARRA SÁNCHEZ, «se trata de una demanda impropia que tiene carácter preparativo del juicio, que es donde se ejerce, en sentido estricto, la pretensión». Podríamos, por lo tanto, distinguir dos fases ${ }^{48}$ : Una primera, de iniciación del proceso mediante dicha demanda sucinta y de "anuncio» de la pretensión; y una segunda, que tendría lugar en la Vista, de ejercicio pleno de la pretensión. Por esta razón, se ponía en tela de juicio la protección del derecho de defensa del demandado, ya que la preparación de su contradicción quedaba circunscrita hasta el momento de la Vista, en el que conocería la pretensión completa del actor ${ }^{49}$.

En su virtud, la doctrina mayoritaria sostenía que, dada la complejidad técnico-jurídica de este proceso, era conveniente presentar una demanda ordinaria o, cuando menos, incluir en ella una sucinta la fundamentación fáctica esencial ${ }^{50}$.

Cabe destacar que existía cierta similitud entre la demanda sucinta y la antigua "papeleta» prevista para iniciar el Proceso Especial de Desahucio en los artículos 1.571 y 720 de la LEC de 1881. Algunos

${ }^{47}$ IBARRA SÁNCHEZ, J. L., op.cit., pág. 181.

${ }^{48}$ Comentario sobre la obra de GUASP DELGADO en la obra de VÁZQUEZ SOTELO, J. L. Ley de Enjuiciamiento Civil, doctrina y jurisprudencia. (ALBÁCAR LÓPEZ, J. L., Director), Tomo II, 4. a Edición, Madrid, 1994, pág. 581.

${ }^{49}$ IBARRA SÁNCHEZ, J. L., op. cit., pág. 184.

${ }^{50} \mathrm{Vid}$. IBARRA SÁNCHEZ, J. L., op. cit., págs. 188 y 189. Así como, HERAS GONZÁLEZ, P., "Juicio verbal: La problemática de las actuaciones previas a la Vista». Boletín de Información del Ministerio de Justicia, n. ${ }^{\circ}$ 1,911, 2002, Madrid, pág. 15; y ACHÓN BRUÑ́n, M. J., Análisis práctico del juicio de desahucio por falta de pago, Barcelona, 2007, págs. 59 y 61. A favor: SAP Madrid (Sección 10. ${ }^{\text {) }}$, núm. 749/2004, de 21 de junio, recurso n. ${ }^{\circ} 357 / 2003$, F. J.3. ${ }^{\circ}$ 
juristas $^{51}$ justificaban la iniciación del proceso mediante dicha papeleta en la ausencia de la obligación legal de comparecer asistido de Abogado y Procurador, por lo que no podía exigírse, en consecuencia, excesiva complejidad técnica y contenido jurídico.

En cualquier caso, no hemos de olvidar que, en todo caso, el actor debe indicar en la demanda, como requisito para su admisión, «las circunstancias concurrentes que pudieran permitir o no, en el caso concreto, la enervación del desahucio» (art. 439.3 LEC). A su vez, puede optar por anunciar su compromiso de condonar todo o parte de la deuda y las costas al arrendatario, a cambio del desalojo voluntario del inmueble en el plazo establecido por el propio actor, en ningún caso inferior a quince días desde la notificación de la demanda; e, igualmente, que se tenga por solicitada la ejecución del lanzamiento a los efectos del artículo 549.3 LEC (art. 437.3 LEC).

\section{B. La cuantía del proceso}

Con anterioridad a la entrada en vigor de la Ley 19/2009, de 23 de noviembre, de medidas de fomento, agilización procesal del alquiler y de la eficiencia energética de los edificios, existía una importante controversia, tanto doctrinal como jurisprudencial, en torno a la cuantía de este proceso de desahucio, derivada de la ambigüedad y escasa concreción de sus preceptos, así como de la falta de consenso acerca de la interpretación de los criterios de determinación de la cuantía, necesaria a la hora de calcular las costas procesales ${ }^{52}$.

La discusión giraba, fundamentalmente, en torno a la interpretación del apartado 9..$^{\circ}$ del artículo 251 LEC, en virtud del cual, «en los juicios sobre arrendamientos de bienes, salvo los que tienen por objeto la reclamación de rentas vencidas, la cuantía de la demanda será el importe de una anualidad de renta, cualquiera que sea la periodicidad con que ésta aparezca fijada en el contrato. No obstante, cuando se reclame la posesión del bien arrendado, se estará a lo dispuesto por la tercera regla de este artículo». Dicha tercera regla determinaba que la cuantía

${ }^{51}$ Entre otros, PEDRÁZ PENALVA, E., «En torno al juicio verbal de la Ley 1/2000, de Enjuiciamiento Civil. Particular consideración de la demanda y la reconvención». La aplicación práctica de la Ley de Enjuiciamiento Civil del 2000, (GÓMEZ COLOMER, J. L. Coordinador), 1. ${ }^{a}$ Edición, Valencia, 2003, p. 171. Así como, BANACLOCHE PALAO, J. y CUBILLO LÓPEZ, I., Aspectos fundamentales de Derecho Procesal Civil, 2. ${ }^{\mathrm{a}}$ Edición, Madrid, 2004, p. 162.

52 FERNÁNDEZ GIL, C., op. cit., pág. 186. 
se correspondería con el valor del inmueble en el momento de interposición de la demanda.

Es cierto que el precepto podía dar lugar a diversas interpretaciones más o menos restrictivas. Por ello que surgieron varias corrientes doctrinales, entre las que destacaremos ${ }^{53}$ : Una primera en favor de una interpretación forzada del artículo y de que la cuantía del proceso de desahucio debía de ser, en todo caso, una anualidad de renta ${ }^{54}$ (art. 251.9. ${ }^{a}$ LEC) ya que, ante todo, estábamos ante un «juicio sobre arrendamiento de bienes» en el que la pretensión principal es la resolución contractual, dejando en un segundo plano la ejecución y, con ello, la pretensión de recuperación posesoria ${ }^{55}$. Otra posición se inclinaba hacia una interpretación literal de la Ley y de la remisión a la regla tercera, lo que implicaba, por tanto, atender al valor del inmueble en el momento de presentación de la demanda como cuantía del proceso $^{56}$ (art. 251.3. ${ }^{\circ}$ LEC). Y por último, la corriente que defendía la aplicación, como criterio de cálculo, del importe de la renta reclamada, teniendo en cuenta que el desahucio por falta de pago se deduce, precisamente, de la obligación impagada (art. 251.1. ${ }^{\circ}$ LEC) $)^{57}$. Esto evidencia la problemática de las «remisiones en cascada».

Ante este panorama, la Ley 19/2009, de 23 de noviembre, modificó el apartado 9. ${ }^{\circ}$ del artículo 251 LEC disipando cualquier duda al decantarse por la primera corriente.

\section{El pago de la Tasa Judicial}

En este punto, la Ley 10/2012, de 20 de noviembre, reguladora de determinadas tasas en el ámbito de la Administración de Justicia y del Instituto Nacional de Toxicología y Ciencia Forense (en adelante, Ley de Tasas Judiciales), establece en su artículo segundo, con carác-

${ }^{53} \mathrm{Vid}$. IBARRA SÁNCHEZ, J. L., op. cit., págs. 196 ss.

${ }^{54}$ A favor: Auto AP Islas Baleares (Sección 5. ${ }^{a}$ ), núm. 17/2001, de 1 de febrero; SAP Málaga (Sección 6. ${ }^{\mathrm{a}}$ ), núm. 1098/2002, de 19 de diciembre, F. J.2. ${ }^{\circ}$; SAP Toledo (Sección 2. ${ }^{\mathrm{a}}$ ), núm. 105/2012, de 13 de abril; SAP Islas Baleares (Sección 5. ${ }^{\mathrm{a}}$ ), núm. 49/2007, de 7 de febrero; SAP Alicante (Sección 1. ${ }^{\text {) }}$ ), núm. 229/2006, de 6 de junio; Auto AP Barcelona (Sección 13. ${ }^{\text {a) }}$, de 30 de junio de 2002.

${ }^{55}$ Vid. IBARRA SÁNCHEZ, J. L., op. cit., p. 197 y 198. ROSELL I GAIROLES, T., "Los procedimientos arrendaticios», La interpretación judicial de la nueva Ley de Enjuiciamiento Civil, (PICÓ Y JUNOY, J., Coordinador), Barcelona, 2002 [versión en línea de VLex], pág. 3.

${ }^{56}$ Se inclinan por esta postura: Vid. GIMENO SENDRA, V., y MORENILLA ALLARD, P., Derecho Procesal Civil II. Procesos Especiales, Madrid, 2005, pág. 128.

${ }^{57}$ En favor: Vid. ACHÓN BRUÑÉN, M. J., Análisis práctico del juicio de desahucio por falta de pago, Barcelona, 2007, pág. 74. 
ter general, que están sometidas al pago de las Tasas Judiciales «las demandas en toda clase de procesos declarativos (...) en el orden jurisdiccional civil».

En primer lugar, hemos de hacer especial referencia a la reforma del artículo 440 LEC introducida por la Ley 37/2011, de 10 de octubre, de medidas de agilización procesal, toda vez que se aprecia un conflicto entre este precepto y el artículo séptimo de la vigente Ley de Tasas Judiciales.

Como ya comentamos, esta Ley de 10 de octubre de 2011 extendió la técnica monitoria al Proceso de Desahucio por Falta de Pago y, en consecuencia, excluyó la aplicación de las normas procesales generales del Juicio Verbal, salvo en aquellos casos en los que el demandado formulase oposición o alegase las circunstancias relativas a la procedencia de la enervación.

Una vez apuntado el anterior extremo, surge el conflicto con el mencionado artículo de la Ley de Tasas Judiciales, en cuanto que prevé como Tasa para el Proceso Monitorio una cantidad fija, no haciendo mención expresa al Proceso de Desahucio por Falta de Pago. En buena lógica se habrá de concretar cuál es la Tasa aplicable a este último proceso, si la propia del Proceso Monitorio Común con razón de la reforma de 2011, o la del Juicio Verbal.

En este sentido, el Ilustre Colegio Nacional de Secretarios Judiciales, ahora Letrados de la Administración de Justicia, estima que resultarán aplicables la Tasa fija prevista para el Juicio Verbal y la variable, por remisión del artículo 6 de la Ley de Tasas Judiciales a las reglas del artículo 252 LEC, toda vez que "cuando las acciones acumuladas fueran la de desahucio por falta de pago (...) y la de reclamación de rentas o cantidades debidas, la cuantía de la demanda vendrá determinada por la acción de mayor valor ${ }^{58}$, por lo que será ésta la cuantía de la base imponible de la Tasa.

Sin embargo y, en sentido contrario, se ha pronunciado la Dirección General de Tributos en una Consulta vinculante ${ }^{59}$-formulada por el Procurador de los Tribunales D. Manuel Pérez Merelles- donde

58 «Guía Práctica para la Aplicación de las Tasas Judiciales. Adaptada al Real Decreto-ley 2/2013, de 22 de febrero». Ilustre Colegio Nacional de Secretarios Judiciales. Director: Ernesto P. Casado Rodríguez. La Ley. Revista Práctica de Tribunales, 24 de febrero de 2013. Edición digital de 7 de marzo de 2013.

${ }^{59}$ Consulta Vinculante interpuesta por D. Manuel Pérez Merelles a la Dirección General de Tributos. Ministerio de Hacienda y Administraciones Públicas. N. ${ }^{\circ}$ Consulta: V1362-13; N. ${ }^{\circ}$ de Registro: 02639-13, Subdirección 07. 
se afirma que en los Procesos de Desahucio por Falta de Pago la Tasa a aplicar sería idéntica a la precisada para el Monitorio

De momento, la solución no está totalmente clara. Tendremos que estar, pues, a la espera de un consenso en la práctica forense, o una reforma legislativa que aclare este extremo.

Por último, hemos de destacar la reciente reforma de la Ley de Tasas llevada a cabo por Ley 25/2015, de 28 de julio, en virtud de la cual las personas físicas quedan exentas del pago de la Tasa.

\section{Régimen de notificaciones}

Tal y como ha dispuesto el Tribunal Constitucional, «la notificación es un elemento esencial para la correcta y escrupulosa constitución de la relación jurídico procesal para entablar y proseguir procesos judiciales con plena observancia de los derechos constitucionales de defensa (artículos 24.1 y 2 CE) que asisten a las partes» ${ }^{60}$.

La problemática que encontramos en el régimen de notificaciones del Proceso de Desahucio por Falta de Pago gira, esencialmente, en torno a la comunicación edictal, regulada en el artículo 164 de la LEC.

La principal crítica doctrinal, parte del tenor literal del artículo 164 LEC, del que no se desprende la necesidad de ninguna labor de investigación del domicilio del demandado con carácter previo a la comunicación en estrados, siendo ello contrario a la reiterada doctrina del Tribunal Constitucional en favor de una actuación prudente por parte de los Tribunales a la hora de recurrir a la comunicación edictal, teniendo en cuenta, sobre todo, la posible afectación de derecho de defensa del demandado (art. $24 \mathrm{CE}$ ).

De conformidad con la doctrina de este Tribunal, la comunicación edictal es una posibilidad excepcional, cuya aplicación ha de ser, en cualquier supuesto, subsidiaria a una labor de investigación por parte del órgano jurisdiccional que, en su caso, lleve a la convicción sobre la imposibilidad de conocer el paradero del demandado ${ }^{61}$. Y es que la comunicación edictal puede atentar gravemente contra el derecho de defensa de la parte demandada, quedando afectos, a su vez, los principios de contradicción, audiencia e igualdad de armas procesales para la defensa.

${ }^{60}$ STC 162/2004, de 4 de octubre y STC 76/2006, de 13 de marzo de 2006.

${ }^{61}$ SSTC 176/2009, de 16 de julio, F. J 2. ${ }^{\circ}$; 306/2006, de 23 de octubre, F. J 2. ; 163/2007, de 2 de julio, F. J 2. ${ }^{\circ}$; 78/2008, de 7 de julio, F. J 2. ${ }^{\circ}$ 
Pese a ello, podemos ver cómo la LEC ha evolucionado en esta materia acercándose cada vez más al régimen del artículo 1.576 de la LEC de 1881, que establecía un sistema de comunicación en estrados prácticamente automática al desconocimiento del paradero del demandado ${ }^{62}$.

Si bien, esta no era la pretensión previa de la LEC del 2000 en el momento de su entrada en vigor pues, inicialmente el artículo 164 LEC hacía referencia a la necesidad de «realizar las averiguaciones a que se refiere el artículo $156 \mathrm{LEC}$ » con anterioridad a proceder a la notificación por medio de edictos, con independencia del proceso del que se tratase.

Fue la Ley 19/2009, de 23 de noviembre, de medidas de fomento y agilización procesal del alquiler y de la eficiencia energética de los edificios, la que introdujo un sistema de comunicación en estrados especial para el Proceso de Desahucio por Falta de Pago, excluyéndolo, por tanto, de la obligatoriedad de la actuación de averiguación previa.

A juicio de cierto sector doctrinal, en puridad se trataba, como afirma PRIETO-CASTRO Y FERRÁNDIZ ${ }^{63}$, de «evitar la frustración del fin ejecutivo rápido del procedimiento de desahucio por medio de cualquier argucia del demandado». Por el contrario, otros autores ${ }^{64}$ sostienen que con este cambio legislativo se pretende proteger al arrendador frente a conductas negligentes o culposas del demandado que impidan su localización, teniendo en cuenta que éste ya debería tener conocimiento de las consecuencias legales de su «huida». Se ha hablado también de la lentitud que aportaba al proceso la realización del conjunto de diligencias de investigación del domicilio.

Si bien los anteriores argumentos podrían llevarnos a pensar que se está "sancionando» mediante notificación edictal -que verdaderamente es un medio de comunicación ficticio que no garantiza la recepción de lo notificado al interesado-, a todo demandado cuyo paradero se desconoce por el juego de la presunción de una conducta dolosa o negligente por su parte.

${ }^{62}$ Artículo 1.576 LEC-1881: "Cuando el demandado no tenga domicilio fijo y se ignore su paradero, se hará la citación en los estrados del Juzgado para que comparezca al juicio verbal (...)».

${ }^{63}$ PRIETO-CASTRO Y FERRÁNDIZ, L., Derecho Procesal Civil, Tomo II, Pamplona, 1961, pp. 15 y16.

${ }^{64}$ Vid. Entre otros, SAMANES ARA, C., citada por BONET NAVARRO, J., Los juicios de desahucio, Especialidades procesales para la recuperación de la posesión de la

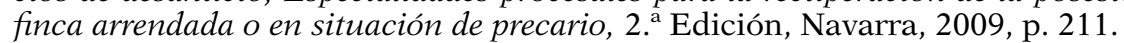


Ahora bien, pese a ser posible la comunicación vía edictos en caso de imposibilidad de localización del demandado, la Jurisprudencia sigue exigiendo del órgano judicial la realización de cuantas actuaciones estime posibles dirigidas a la averiguación del domicilio o paradero del demandado a efectos de que éste pueda ser oído en el proceso y no sea condenado, en su caso, en clara indefensión ${ }^{65}$.

Aunque, no hemos de olvidar que nos encontramos ante un proceso en el que las resoluciones carecen de fuerza juzgada ${ }^{66}$, lo que, en cierta medida, afecta en menor grado el derecho a la tutela judicial efectiva toda vez no se veda completamente el derecho del demandado a una defensa ${ }^{67}$.

En conclusión de lo anteriormente expuesto, tras la trascendental reforma del artículo 164 LEC, en consonancia con la reforma del artículo 155 LEC, que pasó a disponer que si las partes no habían pactado otra cosa, se entendería como domicilio la finca arrendada, se configura un sistema de notificaciones autónomo ${ }^{68}$ para el Desahucio por Falta de Pago en el que, de no ser localizado el demandado en el domicilio que conste en el contrato o, en su defecto, en el propio inmueble arrendado, sin notificación previo de un cambio de domicilio al arrendador al que éste no se hubiera opuesto, se pasará sin ulterior trámite a la comunicación en estrados.

\section{El requerimiento de pago. Posibles conductas del demandado}

La introducción de la figura del «requerimiento de pago» en la tramitación del Proceso de Desahucio por Falta de Pago es una de las

${ }^{65}$ STC (Sala Segunda) 30/2014, de 24 de febrero, F. J.3. ${ }^{\circ}$ A favor: SSTC 40/2005, de 28 de febrero, Recurso de Amparo n. ${ }^{\circ}$ 1923-2002, F. J.2. ${ }^{\circ}$; 293/2005, de 21 de noviembre, Recurso de Amparo n. ${ }^{\circ}$ 6834-2000, F. J.2. ${ }^{\circ}$; 78/2008, de 7 de julio, Recurso de Amparo n. ${ }^{\circ}$ 5258-2005, F. J.2. ${ }^{\circ}$

${ }^{66}$ En sentido, estricto, a juicio de CALAZA LÓPEZ, como especial ejecutivo, presenta los efectos de cosa jugada formal y material, lo cierto es que su objeto varía cada mesa, por lo que basta que transcurra otra mensualidad sin abonar la renta, para se pueda instar de nuevo la acción, de modo que la cosa juzgada tiene un límite temporal, vid., CALAZA LÓPEZ, S., La cosa juzgada, La Ley, Madrid, 2009, págs. 36 y sigs.

${ }^{67}$ Vid. ACHÓN BRUÑÉN, M. J., «Problemas prácticos derivados de la reforma del juicio de desahucio por falta de pago por la Ley de Medidas de Agilización Procesal», Diario La Ley, núm. 7738, Sección Tribuna, noviembre de 2011. Así como, SÁNCHEZ GIMENO, S., «La Modificación de la Ley de Enjuiciamiento Civil Operada por la Ley 37/2011, de 10 de octubre, de Medidas de Agilización Procesal», Actualidad Jurídica Uría Méndez, núm. 31-2012, 2012, pág. 43.

${ }^{68}$ ADÁN DOMÈNECH, F., «Reflexiones sobre la última reforma del juicio verbal arrendaticios», Diario La Ley, núm. 7.289, de 23 de noviembre de 2009, pág. 20. 
manifestaciones más claras de la extensión de la técnica monitoria a este tipo de procesos.

Según lo dispuesto en el artículo 440.3 LEC, una vez presentada la demanda, el Letrado de la Administración de Justicia dictará un Decreto de admisión a trámite de la misma y, posteriormente, requerirá al arrendatario para que, en el plazo máximo de diez días, formule oposición; proceda al desalojo del inmueble; pague las cantidades debidas en caso de haberse acumulado la acción de reclamación de rentas a la de desahucio; o, de pretender la enervación del desahucio, pague la totalidad de las rentas o sumas debidas hasta el momento del pago enervador.

El requerimiento de pago contendrá, además, el señalamiento de las fechas de la vista y del lanzamiento que, en su caso, pudieran tener lugar; así como una serie de apercibimientos. En concreto, se apercibirá al demandado de que, de no desalojar, pagar, enervar u oponerse, o de no comparecer al acto de la vista, se procederá directamente y sin más trámites a la ejecución del desahucio, sin necesidad de notificación posterior (artículo 440.3 LEC). A su vez, en el mismo requerimiento queda citado para recibir la notificación de la Sentencia que, en su caso, pudiera poner fin al proceso (artículo 440.4 LEC).

Las conductas que puede adoptar el demandado una vez que le es notificado el requerimiento de pago son las siguientes:

- Si mantiene una actitud plenamente pasiva, no atendiendo a ninguno de los términos del requerimiento, siguiendo lo dispuesto en el artículo 440.3 LEC, el Letrado de la Admón. de Justicia dictará un Decreto dando por finalizado el proceso, se dará traslado al demandante para que inste el despacho de ejecución de no haberlo solicitado ya en el mismo escrito de la demanda, y se procederá, sin necesidad de notificación al deudor, a la ejecución del desahucio.

- De atender a la petición de desalojo pero no al requerimiento de pago de las cantidades adeudadas, el L. A. J. dictará un Decreto que dé por terminado el procedimiento sólo respecto del desahucio, quedando pendiente, por tanto, la ejecución en relación a la deuda. A continuación, el L. A. J. dará traslado al demandado para que solicite dicha ejecución o, en caso de haberse solicitado ya en la demanda ${ }^{69}$, se procederá directamente a la ejecución de dichas cantidades.

${ }^{69}$ Cabe destacar que, con anterioridad a la entrada en vigor de la Ley 4/2013, de 4 de junio, que modificó los apartados $3 .^{\circ}$ y $4 .^{\circ}$ del artículo 440 LEC, existía una contradic- 
En ambos casos, de acuerdo con el último inciso del artículo 440 LEC, el Decreto que dé por terminado el Juicio de Desahucio, «impondrá las costas al demandado e incluirá las rentas debidas que se devenguen con posterioridad a la presentación de la demanda hasta la entrega de la posesión efectiva de la finca, tomándose como base de la liquidación de las rentas futuras, el importe de la última mensualidad reclamada al presentar la demanda».

- En caso de comparecer y oponerse a las causas que fundamentan el desahucio, se celebrará la Vista, cuya fecha se determinó en el mismo requerimiento. En este caso, será el Juez quien ponga fin al proceso por medio de Sentencia.

- Si bien, de oponerse el demandado y no comparecer posteriormente en la Vista o, de pretender la enervación y que, una vez opuesto el demandante a la misma, aquél no comparezca a la Vista, nuevamente nos encontraremos ante un supuesto que lleva aparejado la ejecución. El proceso terminará por Sentencia y será en la misma donde se fije una nueva fecha para el lanzamiento, puesto que la fijada inicialmente en el requerimiento no sería operativa. Sólo en caso de que no se recurra la Sentencia se procederá al lanzamiento.

- Finalmente, de atender a todas las peticiones del requerimiento, se pondrá fin al Proceso de Desahucio por Falta de Pago por Decreto del L. A. J. y se condenará en costas al demandado.

Cabe destacar, como afirma CASADO ROMÁN, que la reforma llevada a cabo por la Ley 37/2011 no contempla la posibilidad de que sea el Letrado de la Administración de Justicia quien pueda dar por resuelto el contrato de arrendamiento en el Decreto que pone fin al proceso. Es por eso que entiende que debería ser una resolución judicial dictada por el Juez la que declarase la resolución de la relación contractual ${ }^{70}$.

ción entre los artículos 440.3 y 437.3 LEC, en vistas de que el último prevé la posibilidad de que el demandado interese en su escrito de demanda que se «tenga por solicitada la ejecución del lanzamiento en la fecha y hora que se fije por el Juzgado a los efectos señalados en el artículo 549.3»; mientras que el primero, obviando aquél precepto, disponía que el Secretario Judicial tendría que dar «traslado al demandante para que inste el despacho de ejecución, bastando para ello con la mera solicitud». Ahora ya no existe tal contradicción.

${ }^{70}$ Vid. CASADO ROMÁN, J., «Aspectos controvertidos de la demanda en el Proceso de Desahucio por Falta de Pago», Diario la Ley, núm. 8123, Sección Doctrina, de 10 de julio de 2013, p. 10/17. 


\section{Condena en costas}

Pese a que la propia Exposición de Motivos de la Ley 37/2011 señalaba que el objetivo perseguido por la reforma era «extender el sistema del Juicio Monitorio a los Juicios de Desahucio por Falta de Pago", el desahucio, lejos de transformarse en un Proceso Monitorio, se mantiene como una especialidad del Juicio Verbal.

Por tanto, hemos de entender que serán aplicables a estos Procesos de Desahucio las normas sobre condena en costas previstas con carácter general para los procesos declarativos en el capítulo VII del Título I del Libro II (artículos 394 y siguientes), no siendo posible trasladar las previsiones del Proceso Monitorio de no imposición de costas, con la excepción del Monitorio especial de la Ley de Propiedad Horizontal.

El primer problema que planteó la Ley 37/2011, de medidas de agilización procesal, respecto a la cuestión de condena en costas, fue que nada mencionaba al referirse al Decreto del L. A. J. Por otro lado, la LEC, en su artículo 440, tampoco resolvía en modo alguno esta cuestión.

Por tanto, la falta de regulación expresa y la analogía del procedimiento con el Proceso Monitorio generaron un amplio debate en torno a la procedencia o improcedencia de costas. Una consolidada doctrina jurisprudencial entendía que, estando ante un procedimiento que exige la intervención de Abogado y Procurador, aunque utilice la técnica monitoria, ha de estar sometido a lo establecido en los artículos 394 y siguientes de la LEC y, por tanto, el Decreto del L. A. J. puede y debe condenar en $\operatorname{costas}^{71}$.

Ahora bien, la Ley 4/2013, de 4 de junio, de medidas de flexibilización y fomento del mercado del alquiler ha colmado esta laguna, al modificar el artículo 440.3 LEC y regular expresamente la imposición de costas por el L. A. J. en el Decreto. No tenía mucho sentido que el arrendador tuviese que soportar los gastos de Abogado y Procurador, habiéndose visto obligado a acudir a los Tribunales para recuperar la posesión de un inmueble arrendado. En este mismo sentido, el artículo 22.5 LEC.

${ }^{71} \mathrm{Al}$ respecto, Auto de la AP Girona (Sección 1. a), núm. 158/2012, de 11 de octubre. 


\section{Especialidades en materia de recursos}

Los intentos del legislador por suplir las deficiencias del Juicio de Desahucio por Falta de Pago han sido continuos. En la materia que nos ocupa, la Ley 13/2009, de 3 de noviembre, introdujo diferentes reformas sobre los recursos del Título IV del Libro II de la LEC.

En primer lugar, destaca el artículo 250.1 LEC, donde se establece que los Juicios Verbales tramitados por razón de la materia, como son los Desahucios por Falta de pago, siempre son susceptibles de ser recurridos en apelación, con independencia de su cuantía.

Teniendo en cuenta lo anteriormente expuesto, nos centraremos a continuación en la reforma introducida por la Ley 37/2011, de 10 de octubre, de medidas de agilización procesal, del artículo 449 LEC, que regula el derecho a recurrir en casos especiales y configura el pago de las rentas vencidas como requisito de procedibilidad exigible, tanto en los recursos ordinarios como extraordinarios, devolutivos y contra Sentencias y Autos que pongan fin a todo proceso que lleve aparejado el lanzamiento.

Así pues, en los procedimientos donde se acumulen las acciones de reclamación de cantidad y de desahucio por falta de pago, si el demandado entrega la finca al actor, pero pretende recurrir en apelación la reclamación de las cantidades adeudadas, también será exigible el pago de las rentas vencidas. La finalidad es evitar un enriquecimiento injusto del recurrente frente al empobrecimiento del titular del inmueble.

El legislador, configura dicho requisito del artículo 449 LEC como una carga procesal cuyo incumplimiento lleva consigo la pérdida del derecho a recurrir. No se concibe pues, como una obligación, susceptible de ser exigida, sino como una actuación que, de no realizarse en el momento determinado por la Ley, resulta insubsanable ${ }^{72}$. Ahora bien,

${ }^{72}$ Como se desprende de la doctrina del Tribunal Constitucional en sus SSTC 344/1993, de 22 de noviembre; 346/1993, de 22 de noviembre; 100/1993, de 22 de marzo; así como la reciente Sentencia del Tribunal Supremo 84/2013, dictada por la Sala Primera el día 26 de febrero que, en su Fundamento jurídico tercero, indica que el pago de las rentas vencidas constituye un requisito insubsanable:

«(...) no es posible intentar subsanar el pago con posterioridad al momento de interponer el recurso; sólo podrá subsanar la falta de acreditación del pago que debió hacerse antes de interponer el recurso. Manifiesta el recurrente que no se le dio la posibilidad de subsanar tal defecto, pero tampoco lo ha intentado al interponer el presente recurso extraordinario de infracción procesal, en el que ninguna referencia se hace a que hubiese efectuado el pago antes de interponer el recurso. Es decir, pudo subsanar la acreditación del pago ante esta Sala, y no lo efectuó, de lo que se evidencia que la única 
como declaró el Tribunal Supremo en su Sentencia, de 30 de noviembre del 2011, no es posible subsanar la falta de pago con posterioridad a la interposición del recurso, pero sí la falta de acreditación documental de que en el momento de la interposición de la apelación se había cumplido con el depósito o consignación de aquellas cantidades ${ }^{73}$.

Cabe destacar, además, que, como afirma la mencionada Sentencia del Tribunal Supremo, el abono de las cantidades debidas deberá realizarse en efectivo, no permitiéndose $\mathrm{aval}^{74}$.

La particularidad de este depósito para recurrir en los procesos arrendaticios reside en que no es exigible para los recursos formulados oralmente en el acto de la Vista.

Respecto al recurso de queja, a la vista del 2. ${ }^{\circ}$ párrafo del artículo 494 LEC introducido por la Ley 19/2009, de 23 de noviembre, que dispone que: "No procederá el recurso de queja en los procesos de desahucios de finca urbana y rústica, cuando la Sentencia que procediera dictar en su caso no tuviese la consideración de cosa juzgada», queda claro que no cabe contra la denegación de apelación en un desahucio, y ello porque el Juicio Verbal de desahucio por falta de pago es un juicio de naturaleza sumaria, cuya sentencia no producirá efectos de cosa juzgada (art. 447 LEC).

\section{La ejecución del desahucio. El lanzamiento}

En relación al lanzamiento, ha sido la reciente Ley 4/2013, de 4 de junio, de medidas de flexibilización y fomento del mercado del alquiler de vivienda, la que ha introducido la modificación más relevante ${ }^{75}$.

El objetivo principal de la reforma reside en impulsar el lanzamiento y solventar los problemas que puede acarrear al arrendador la pasividad del arrendatario en la entrega de la posesión del inmueble. Como veremos, se pretende ofrecer una mayor garantía al arrendador en caso de incumplimiento, pero protegiendo, a su vez, la posición del

actividad que desarrolló para cumplir con lo dispuesto en el art. 449 de la LEC fue la constitución del aval, y en su análisis hemos de centrarnos.»

${ }^{73}$ STS de 30 de noviembre de 2011, Recurso de Casación núm. 2059/2006.

${ }^{74}$ STS 30 de noviembre de 2011: «El legislador exige la acreditación de tener satisfechas las rentas (artículo 449.1 LEC) y la constitución de un aval a disposición del Juzgado no es un medio idóneo similar al pago, por lo que procede desestimar el recuso interpuesto, no habiéndose violado el derecho a la tutela judicial efectiva (artículo 24 de la Constitución).» En este mismo sentido: STS 84/2013 (Sala Primera), de 26 de febrero.

${ }^{75}$ Vid. POSTIGO GUTIÉRREZ, A. y CASADO ROMÁN, J., "La ejecución de las resoluciones dictadas en los procesos de desahucio», Diario La Ley. Núm. 8336/2013; ISSN 1138-9907, 2013, pág. 1. 
demandado, dotándole de la posibilidad de oponerse al lanzamiento y acudir a la celebración de una vista oral.

Una modificación significativa es la introducida al artículo 440.3 LEC, al vincular el lanzamiento a la falta de oposición del demandado. Así, si éste no atiende el requerimiento de pago o no comparece para oponerse o allanarse, el L. A. J, mediante Decreto, dará por terminado el juicio y se llevará a cabo el lanzamiento en la fecha señalada.

Por otro lado, respecto al plazo para la práctica del lanzamiento, la Ley 4/2013, de medidas de flexibilización y fomento del mercado del alquiler de vivienda, ha reformado también el apartado $4 .^{\circ}$ del artículo 440 LEC. Ahora bien, lejos de agilizar el plazo para su realización, lo aumenta dado que establece un plazo de treinta días hábiles, en el que se han de descontar Sábados, Domingos y festivos, por lo que el plazo es mayor al antecedente de un mes, computándose éste de fecha a fecha sin necesidad de descontar los días inhábiles.

Hemos de tener en cuenta, además, que éste plazo no quedaría sin efecto en el supuesto de que el Juicio de Desahucio terminase por sentencia, pues el lanzamiento, por modificación del artículo 549.4 LEC, se podría practicar sin necesidad de espera de los veinte días desde la notificación de la sentencia para su firmeza. La finalización del proceso mediante sentencia no implicaría, por lo tanto, la suspensión del lanzamiento.

Otra de las reformas introducidas por la Ley que tratamos, es la del artículo 549.3 LEC, que prevé la posibilidad de solicitar en la misma demanda la ejecución, tanto del Decreto como de la Sentencia que, en su caso, pudiera dictarse. Con respecto a la regulación anterior, supone un pequeño avance para la agilización del procedimiento pues antes tan solo se permitía introducir en la demanda la solicitud de ejecución de la Sentencia que pusiera fin al procedimiento. Nada se decía sobre el Decreto del L. A. J.

Respecto al señalamiento del día y hora para la práctica del lanzamiento, en virtud del apartado 3.4.d) de la Disposición Adicional Quinta de la LEC, se trata de una función propia de las Oficinas de Señalamientos Inmediatos. Ésta procederá, en los términos previstos en el artículo 440.3 LEC, a fijar la fecha para llevar a cabo la práctica de la diligencia de lanzamiento en un plazo inferior a un mes desde la fecha en que se hubiera señalado la correspondiente Vista ${ }^{76}$.

\footnotetext{
${ }^{76}$ Especial referencia al recurso de inconstitucionalidad interpuesto contra diversos preceptos de la Ley Orgánica 19/2003, de 23 de diciembre, de modificación de la LOPJ, y resuelto por la STC 224/2012, de 29 de noviembre de 2012.
} 
Por otra parte, añade la Ley 4/2013 un nuevo párrafo al artículo 703.1 LEC, relativo a la entrega de bienes inmuebles en virtud de Auto de despacho de ejecución. De este modo, con la clara intención de evitar demoras en la práctica del lanzamiento, con autorización previa del L. A. J., podrá realizarse con la única presencia de un funcionario Gestor que, en su caso, podrá solicitar el auxilio de la fuerza pública.

Cabe señalar la previsión del artículo 704 LEC, referente al aplazamiento del desahucio cuando lo que se pretende desahuciar resulte ser una vivienda familiar. Para acogerse a dicho supuesto, el demandado deberá acreditar previamente el carácter de vivienda habitual de la finca arrendada, mediante la aportación de documentos públicos que lo acrediten. Será el L. A. J. encargado de la ejecución y fedatario público, quien valore las circunstancias concurrentes para la concesión del plazo del mes previsto en dicho artículo, así como su prórroga. Dicha resolución adoptará la forma de Decreto y contra el mismo cabría interponer recurso de reposición ${ }^{77}$.

Ahora bien, como señala VENDRELL SANTIVERI, ${ }^{78}$ se ha de hacer hincapié en el hecho de que el plazo fijado en el artículo 440 LEC deja sin efecto el plazo de protección de la vivienda familiar del artículo 704 LEC, salvo en aquellos casos en que, por cualquier motivo, no hubiese podido llevarse a cabo el lanzamiento en la fecha fijada en la resolución judicial.

Por otro lado, respecto a la obligación que tiene el demandado de retirar del inmueble todos los bienes de su pertenencia o sobre los que ejerza posesión, en el caso de no hacerlo, «se considerarán abandonados» (artículo 703.1 LEC). Por ello, es importante señalar su trascendencia jurídica, ya que, en el supuesto de que no se proceda al desalojo de los bienes muebles, éstos podrán ser adquiridos por usucapión por parte del actor, en virtud del artículo 610 del Código Civil.

${ }^{77}$ La Ley 13/2009, de 3 de noviembre, de reforma de la legislación procesal para la implantación de la nueva Oficina Judicial, ampliando las competencias atribuidas al Secretario Judicial, confiriéndole la facultad de dictar resoluciones susceptibles de ejecución, ha motivado la necesidad de articular un sistema de recursos contra las mismas que garanticen los derechos de quienes se sientan perjudicados por dichas resoluciones.

${ }^{78} \mathrm{Vid}$. VENDRELL SANTIVERI, «El lanzamiento tras la reforma de la Ley 19/2009, de 23 de noviembre, de medidas de fomento del alquiler» Práctica de Tribunales, n. ${ }^{\circ}$ 71, mayo de 2010, La Ley. Por remisión de FERNÁNDEZ GIL, C., op. cit., pág. 322 . 
Otro aspecto a tener en cuenta son las circunstancias ${ }^{79}$ durante la práctica del lanzamiento, las cuales pueden dar lugar a impedir o dificultar la entrega de la posesión. Por ejemplo, es posible encontrarse con que el inmueble esté ocupado por terceras personas, personas mayores dependientes, enfermos o menores. Ante dichas circunstancias, el Servicio Común Procesal del Juzgado que conoce del asunto, podrá instar el auxilio de la autoridad pública, así como de entidades públicas que puedan participar en la efectividad del lanzamiento. Todos los gastos ocasionados por dicha asistencia deberán ser sufragados por la parte ejecutante, sin perjuicio de que, posteriormente, puedan ser repercutidos a la parte ejecutada a través de la tasación de costas, en la forma prevista en los artículos 241 y 394 LEC.

\section{CONCLUSIONES}

I. Nos encontramos ante un proceso de gran relevancia en la práctica forense pues, constituye el cauce a través del cual el arrendador ejercita su derecho a la tutela judicial efectiva, reconocido en el artículo 24 de nuestra Constitución, ante una situación de impago de renta o cantidad asimilada. En concreto, pretende la tutela sumaria del derecho posesorio del titular del inmueble ante un incumplimiento contractual.

II. Como consecuencia de esa trascendencia práctica y al afectar a mayor abundamiento a factores económicos como pueda ser el fomento del mercado del alquiler, el Juicio de Desahucio por falta de pago ha sido objeto de numerosas y sustanciales reformas legislativas tendentes a su agilización y, sobre todo, a la reducción de trámites. Se ha buscado, a lo largo de más de una década, que el arrendador recupere la plena confianza en la Administración de Justicia para la resolución de conflictos. Para ello, se refuerza la protección jurídica del actor en esta clase de procedimientos, procurando, además, la celeridad en su resolución.

III. Dos de las reformas esenciales en la materia, fueron, de una parte, la ampliación de las funciones del Secretario Judicial como

${ }^{79}$ Respecto a estas circunstancias especiales que pudieran acaecer a la hora de la ejecución del lanzamiento, señalar lo resuelto por una reciente resolución del Juzgado de 1. ${ }^{a}$ Instancia núm. 39 de Madrid, dictada el 6 de marzo de 2013, con número de recurso: 1649\12. Por medio de esta resolución el Juez decidió suspender el lanzamiento de una madre con tres hijos menores de edad acordado en un procedimiento de desahucio por falta de pago, pero no por un mes, sino hasta la terminación del curso escolar de los menores, lo que significaba en el presente caso un plazo de cuatro meses. La medida se fundamenta en el superior interés del menor reconocido en la Ley Orgánica 1/1996, de 15 de enero, de protección de los menores. 
impulsor del procedimiento a través del Decreto, llevada a cabo por la Ley 13/2009, de 3 de noviembre, de reforma de la legislación para la implantación de la nueva Oficina Judicial; y de otra, la extensión de la técnica monitoria a esta clase de procesos por la renombrada Ley 37/2011, de 10 de octubre, de medidas de agilización procesal.

IV. Esta última reforma, en particular, supuso una auténtica ruptura con el pasado. La aprobación de la LEC de 2000, suprimió los procesos especiales de la LEC de 1881, entre ellos, el Juicio de Desahucio, con la intención de aunar todos los procesos en un mismo texto legal mediante criterios unificadores. Con ello, el Proceso de Desahucio por Falta de Pago se configuró como una mera especialidad del juicio verbal. Formalmente, el proceso perdió su autonomía. Si bien, con la introducción de la técnica monitoria en su tramitación, el Proceso de Desahucio por Falta de Pago recobra, en gran medida, dicha autonomía y ve acentuado su carácter de «especialidad» frente a las normas generales del juicio verbal.

V. Como hemos visto a lo largo de este estudio, ha sido amplia la problemática de este proceso, en particular ante la dispersión de los preceptos reguladores a lo largo de toda la LEC, que en muchas ocasiones, ha llevado a confusión y a interpretaciones dispares. Y es que, verdaderamente estamos ante un proceso cargado de especialidades y matices propios, que, si bien no constituye un proceso especial en sentido formal, tampoco es un proceso sujeto a normas generales. Evidencia de lo anterior es que pese a ser una especialidad del Juicio verbal, su tramitación se caracteriza por estar notablemente influida por la técnica monitoria. Es más, en múltiples casos, de proceder la aplicación de normas generales, dada la especialidad de este proceso, surge el interrogante de si, incluso, dichos preceptos también deberían ser matizados en su aplicación. En definitiva, todo ello dificulta su estudio y, por supuesto, afecta a la seguridad jurídica pues, son frecuentes los supuestos de Jurisprudencia menor contradictoria en relación a la materia que nos ocupa.

VI. En el proceso, el «requerimiento de pago» pasa a ser una auténtica "clave de bóveda», requerimiento éste dictado por el L.A.J. una vez analizada y admitida la demanda. Mediante él, legalmente se concretan ciertas consecuencias procesales para cada una de las posibles conductas del demandado ante su recepción, con lo que puede afirmarse que se dota al proceso de un mayor dinamismo. Manifestación clara de ello es, precisamente, la asociación de una ejecución directa a la pasividad del demandado frente el requerimiento de pago y a su no comparecencia. 


\section{BIBLIOGRAFÍA}

\section{Obras y artículos doctrinales}

ACHÓN BRUÑÉN, M. J., Análisis práctico del juicio de desahucio por falta de pago, Barcelona, 2007.

- "Cantidades debidas que pueden dar lugar al juicio de desahucio», VLex, Id. VLEX-464637. Disponible en: http://libros-revistas-derecho.vlex.es/vid/cantidades-debidas-dar-lugar-desahucio-464638

— «Demanda del juicio de desahucio», VLex, Id. VLEX-464619. Disponible en: http://libros-revistas-derecho.vlex.es/vid/demanda-juicio-desahucio-464619

- "Problemas relativos a la legitimación en el juicio de desahucio», VLex, Id. VLEX-464616. Disponible en: http://libros-revistas-derecho.vlex.es/vid/relativos-legitimacion-juicio-desahucio-464616

- «Problemas prácticos derivados de la reforma del juicio de desahucio por falta de pago por la Ley de Medidas de Agilización Procesal», Diario La Ley, núm. 7738, Sección Tribuna, noviembre de 2011. Disponible en: http://dialnet.unirioja.es/servlet/ articulo?codigo $=3765895$

ADÁN DOMÈNECH, F., «Reflexiones sobre la última reforma del juicio verbal arrendaticios», Diario La Ley, núm. 7.289, de 23 de noviembre de 2009. Disponible en: http://dialnet.unirioja.es/servlet/ articulo?codigo $=3075553$

BANACLOCHE PALAO, J. y CUBILLO LÓPEZ, I., Aspectos fundamentales de Derecho Procesal Civil, 2. ${ }^{\text {a }}$ Edición, Madrid, 2004.

BONET NAVARRO, J., «La pluralidad subjetiva en los procesos civiles caracterizados por la llamada "técnica monitoria»», Revista Jurídica de Castilla y León, núm. 9, Mayo de 2006. Disponible en: http://www.uv.es/ ripj/obraspdf/17Lapluralidad.pdf

- Los juicios de desahucio, Especialidades procesales para la recuperación de la posesión de la finca arrendada o en situación de precario, 2. ' Edición, Navarra, 2009.

CALAZA LÓPEZ, S., La cosa juzgada, La Ley, Madrid, 2009.

CONTIJOCH PRATDESABA, R., «Posibilidad de la acumulación de las acciones de desahucio y de reclamación de rentas contra el arrendatario y los fiadores solidarios» Revista Profesional de Admi- 
nistradores de Fincas de Cataluña, núm. 69, Barcelona, Primer Trimestre, 2007.

CORTÉS DOMÍNGUEZ, V. y MORENO CATENA, V., Derecho Procesal Civil. Parte Especial, 7. a Edición, Valencia, 2013.

FERNÁNDEZ GIL, C., El desahucio «exprés» por falta de pago. Legislación, comentarios y formularios, [soporte digital], 2. ${ }^{a}$ Edición, Madrid, 2013.

GARBERÍ LLOBREGAT, J., Los nuevos juicios verbales de desahucio en la Ley de Enjuiciamiento Civil, Barcelona, 2009.

GIMENO SENDRA, V. y MORENILLA ALLARD, P., Derecho Procesal Civil II. Procesos Especiales, Madrid, 2005.

GUDÍN RODRÍGUEZ-MAGARIÑOS, A. E., «La regulación del requerimiento previo en el juicio de desahucio tras la Ley de Medidas de Agilización Procesal», La Ley, núm. 17714/2011, 2011. http://dialnet.unirioja.es/servlet/articulo?codigo $=3821921$

IBARRA SÁNCHEZ, J. L., Teoría y práctica de los juicios verbales de desahucio. El juicio monitorio de desahucio por falta de pago, 2. Edición, Madrid, 2013.

LORCA NAVARRETE, A. M., «Comentario al artículo 437»Comentarios a la Nueva LEC. Tomo II, (Director: LORCA NAVARRETE, A. M. y Coordinador: GUILARTE GUTIÉRREZ, V). Ed. Lex Nova, Valladolid, 2000.

LOSCERTALES FUERTES, D., «La adjudicación judicial del uso de la vivienda familiar por separación o divorcio de uno de los cónyuges y sus diferentes situaciones.» Revista Sepin, Arrendamientos Urbanos, Núm. 229, Octubre de 2002. Disponible en: http://www.sepin. es/servicios_n/

MAGRO SERVET, V., «La regulación del juicio de desahucio en la Ley 1/2000, de 7 de enero, de Enjuiciamiento Civil». Revista Sepín. Arrendamientos Urbanos. N. ${ }^{\circ}$ 208-A. Noviembre 2000. Disponible en: http://vlex.es/tags/sepin-740603

MARTÍN CONTRERAS, L., "La enervación», Revista Arrendamientos Urbanos Sepín, núm. 246, abril, 2004, Pozuelo de Alarcón (Madrid). Disponible en: http://www.sepin.es/servicios_n/ 
MONTERO AROCA, J. y FLORS MATÍES, J., Tratado de Juicio Verbal, 2. ${ }^{\text {a }}$ Edición, Navarra, 2004.

OBÓN DÍAZ, A., «Regulación actual del proceso de desahucio: Especial referencia al desahucio por falta de pago como juicio rápido y sumario", Noticias Jurídicas, Marzo de 2004.

PEDRÁZ PENALVA, E., «En torno al juicio verbal de la Ley 1/2000, de Enjuiciamiento Civil. Particular consideración de la demanda y la reconvención». La aplicación práctica de la Ley de Enjuiciamiento Civil del 2000, (GÓMEZ COLOMER, J. L. Coordinador), 1. ${ }^{a}$ Edición, Valencia, 2003.

PINTÓ RUÍZ, J. J., «Responsabilidad de los herederos», Noticias Jurídicas, Noviembre de 2005. Disponible: http://noticias.juridicas. com/articulos/45-Derecho-Civil/200511-365614151010523180.html

POSTIGO GUTIÉRREZ, A. y CASADO ROMÁN, J., «La ejecución de las resoluciones dictadas en los procesos de desahucio", Diario La Ley. Núm. 8336/2013; ISSN 1138-9907, 2013. Disponible en: http:// dialnet.unirioja.es/servlet/articulo?codigo $=4455186$

PRIETO-CASTRO Y FERRÁNDIZ, L., Derecho Procesal Civil, Tomo II, Pamplona, 1961.

RAMOS MÉNDEZ, F., Derecho procesal civil, Tomo II, 5. ${ }^{a}$ Edición, Barcelona, 1992.

ROSELL I GAIROLES, T., «Los procedimientos arrendaticios», La interpretación judicial de la nueva Ley de Enjuiciamiento Civil, (PICÓ Y JUNOY, J., Coordinador), Barcelona, 2002 [versión en línea de VLex]. Disponible en: http://libros-revistas-derecho.vlex.es/ vid/interpretacion-judicial-enjuiciamiento-278487

SEOANE SPIEGELBERG, J. L., "Algunas cuestiones puntales de legitimación en los procesos arrendaticios urbanos: Su tratamiento en la LEC 2000", Repositorio de la Universidade Da Coruña, Universidade Da Coruña, A Coruña, 2002. Disponible en: http://ruc.udc.es/ dspace/handle/2183/2180

TRIGO SIERRA, E. y PÉREZ-PUJAZÓN MILLÁN, M. E., «Cuestiones Procesales Prácticas Relativas al Juicio de Desahucio por impago de Rentas», Actualidad Jurídica Uría Méndez. Núm. 15-2006, 2006. Disponible en: http://www.uria.com/documentos/publicaciones/1612/documento/art03.pdf?id=2122 
VÁZQUEZ SOTELO, J. L., Ley de Enjuiciamiento Civil, doctrina y jurisprudencia. (ALBÁCAR LÓPEZ, J. L., Director), Tomo II, 4. ${ }^{a}$ Edición, Madrid, 1994.

\section{Recursos web}

ÁLVAREZ SÁNCHEZ, J. I., VV. AA.: Encuesta Jurídica, «Acumulación de acciones de desahucio por falta de pago y reclamación de rentas. A la vista del artículo 447.2 LEC, ¿La Sentencia firma en cuanto a la reclamación económica no tiene efectos de cosa juzgada? En este caso, ¿Cuál sería el proceso posterior?», Revista Arrendamientos Urbanos Sepín, n. ${ }^{\circ} 218$, de Octubre de 2002, Las Rozas, (Madrid). Disponible en: [Día de consulta: 29/05/2014]: http:// www.sepin.es/servicios_n/

Consulta Vinculante interpuesta por D. Manuel Pérez Merelles a la Dirección General de Tributos. Ministerio de Hacienda y Administraciones Públicas. N. ${ }^{\circ}$ Consulta: V1362-13; N. ${ }^{\circ}$ de Registro: 02639-13, Subdirección 07. Disponible en: http://petete.minhap.gob.es/Scripts/ know3.exe/tributos/CONSUVIN/texto.htm?NDoc $=26385 \&$ Consulta $=$. EN+NUM-CONSULTA+\%28V1362-13\%29\&Pos=0\&UD=1

CREMADES MORANT, J., VV. AA.: Encuesta Jurídica, «Acumulación de acciones de desahucio por falta de pago y reclamación de rentas. A la vista del artículo 447.2 LEC, ¿La Sentencia firma en cuanto a la reclamación económica no tiene efectos de cosa juzgada? En este caso, ¿Cuál sería el proceso posterior?», Revista Arrendamientos Urbanos Sepín, n. ${ }^{\circ} 218$, de Octubre de 2002, Las Rozas (Madrid). Disponible en: http://www.sepin.es/servicios_n/

«Guía Práctica para la Aplicación de las Tasas Judiciales. Adaptada al Real Decreto-Ley 2/2013, de 22 de febrero». Ilustre Colegio Nacional de Secretarios Judiciales. Director: Ernesto P. Casado Rodríguez. La Ley. Revista Práctica de Tribunales, 24 de febrero de 2013. Edición digital de 7 de marzo de 2013. Disponible en: http://www.icacordoba. com/leer-colegio-abogados-cordoba.php?id=00000151\&sec=

O’CALLAGAN MUÑOZ, X, VV. AA., Encuesta jurídica, «Acumulación de acciones de desahucio por falta de pago y reclamación de rentas. A la vista del artículo 447.2 LEC, ¿La Sentencia firma en cuanto a la reclamación económica no tiene efectos de cosa juzgada? En este caso, ¿Cuál sería el proceso posterior?», Revista Arrendamientos Urbanos, n. ${ }^{\circ}$ 218, Madrid. 


\section{VI. ÍNDICE DE RESOLUCIONES JUDICIALES CITADAS}

\section{Cuantía}

Audiencia Provincial de las Islas Baleares (Sección 5. a). Sentencia núm. 17/2001, de 1 de febrero.

Audiencia Provincial de Barcelona (Sección 13.a ). Auto de 30 de junio de 2002.

Audiencia Provincial de Málaga (Sección 6. ${ }^{a}$ ). Sentencia núm. 1098/2002, de 19 de diciembre.

Audiencia Provincial de Alicante (Sección 1. ${ }^{a}$ ). Sentencia núm. 229/2006, de 6 de junio.

Audiencia Provincial de las Islas Baleares (Sección 5. ${ }^{a}$ ). Sentencia núm. 49/2007, de 7 de febrero.

Audiencia Provincial de Toledo (Sección 2. ${ }^{\mathrm{a}}$ ). Sentencia núm. 105/2012, de 13 de abril.

\section{Costas}

Audiencia Provincial de Girona (Sección 1. a). Auto 158/2012, de 11 de octubre.

\section{Ejecución del desahucio}

Tribunal Constitucional (Pleno). Sentencia núm. 224/2012, de 29 de noviembre (BOE núm. 313, de 29 de diciembre de 2012). Recurso de inconstitucionalidad núm. 1933-2004.

Juzgado de Primera Instancia núm. 39 de Madrid, de 6 de marzo de 2013. Número de recurso: 1649/12.

\section{Enervación del desahucio}

Audiencia Provincial de Asturias (Sección 4. ${ }^{\mathrm{a}}$ ). Sentencia núm. $365 / 2002$, de 9 de julio.

Audiencia Provincial de las Islas Baleares (Sección 3. ${ }^{a}$ ). Sentencia núm. 213/2003, de 3 de abril.

Audiencia Provincial de Barcelona (Sección 13. a). Sentencia núm. 652/2004, de 30 de septiembre. 
Audiencia Provincial de Murcia (Sección 3. ${ }^{a}$ ). Sentencia núm. $52 / 2005$, de 24 de febrero.

Audiencia Provincial de La Rioja (Sección 1. ${ }^{\mathrm{a}}$ ). Sentencia núm. 79/2005, de 18 de marzo.

Audiencia Provincial de Castellón (Sección 1. ${ }^{\mathrm{a}}$ ). Sentencia núm. 125/2005, de 30 de junio.

Audiencia Provincial de Murcia (Sección 3. ${ }^{\text {) }}$. Auto 76/2005, de 1 de julio.

Audiencia Provincial de Alicante (Sección 5. ${ }^{\mathrm{a}}$ ). Sentencia núm. 377/2006, de 26 de octubre.

Audiencia Provincial de las Islas Baleares (Sección 3. a). Sentencia núm. 174/2007, de 7 de mayo.

Audiencia Provincial de Pontevedra (Sección 1. ${ }^{\mathrm{a}}$ ). Sentencia núm. 158/2012, de 29 de marzo.

Audiencia Provincial de La Rioja (Sección $1 .^{\mathrm{a}}$ ). Sentencia núm. 136/2013, de 15 de abril.

Tribunal Supremo (Sala de lo Civil). Sentencia núm. 193/2009, de 26 de marzo.

Tribunal Supremo (Sala de lo Civil, Sección 1. a). Sentencia núm. 684/2009, de 20 de octubre.

Tribunal Supremo (Sala de lo Civil). Sentencia núm. 180/2014, de 27 de marzo.

\section{Legitimación procesal}

Audiencia Provincial de Madrid (Sección 18. ${ }^{\mathrm{a}}$ ), de 8 de marzo del 2000.

Audiencia Provincial de Málaga (Sección 6. ${ }^{a}$ ). Sentencia núm. 464/2000, de 21 de junio.

Audiencia Provincial de Vizcaya (Sección 5. ${ }^{a}$ ). Sentencia núm. 763/2000, de 6 de septiembre.

Audiencia Provincial de Murcia (Sección 5. ${ }^{a}$ ). Sentencia núm. 147/2000, de 9 de octubre.

Audiencia Provincial de Asturias (Sección 4. ${ }^{a}$ ). Sentencia núm. 231/2001, de 10 de mayo.

Audiencia Provincial de Guadalajara. Sentencia núm. 75/2002, de 27 de febrero de 2002. 
Audiencia Provincial de Ourense (Sección 2. ${ }^{a}$ ). Sentencia núm. 116/2002, de 22 de marzo.

Audiencia Provincial de Cáceres (Sección 1.ª). Sentencia núm. 153/2002, de 27 de junio.

Audiencia Provincial de Málaga (Sección 6. ${ }^{\mathrm{a}}$ ). Sentencia núm. 848/2002, de 22 de noviembre.

Audiencia Provincial de Madrid (Sección 14. ${ }^{a}$ ). Sentencia núm. 9/2003, de 23 de diciembre.

Audiencia Provincial de Valladolid (Sección 1. ${ }^{\mathrm{a}}$ ). Sentencia núm. 245/2004, de 16 de julio.

Audiencia Provincial de Islas Baleares (Sección 3. ${ }^{\text {) }}$. Sentencia núm. 423/2004, de 7 de octubre.

Audiencia Provincial de Almería (Sección 3. ${ }^{a}$ ). Sentencia núm. 29/2005, de 18 de febrero.

Audiencia Provincial de Cádiz (Sección 1. a). Sentencia núm. 59/2005, de 15 de abril.

Audiencia Provincial de Las Palmas (Sección 3.a). Sentencia núm. 3/2006, de 11 de enero.

Audiencia Provincial de Vizcaya (Sección 5. ${ }^{a}$ ). Sentencia núm. $56 / 2006$, de 2 de febrero.

Audiencia Provincial de Cádiz (Sección 2. ${ }^{\mathrm{a}}$ ). Sentencia núm. 158/2008, de 22 de abril.

Audiencia Provincial de Barcelona (Sección 13.a ). Sentencia núm. $553 / 2008$, de 14 de octubre.

Audiencia Provincial de Sevilla (Sección $6 .^{\mathrm{a}}$ ). Sentencia núm. 142/2009, de 30 de marzo.

Audiencia Provincial de Alicante (Sección 5. a). Sentencia núm. 378/2009, de 2 de diciembre.

Audiencia Provincial de Alicante (Sección 5. ${ }^{a}$ ). Sentencia núm. 70/2010, de 18 de febrero.

Audiencia Provincial de Zaragoza (Sección $4 .^{\mathrm{a}}$ ). Sentencia núm. 489/2010, de 5 de noviembre.

Audiencia Provincial de Madrid (Sección 10. ${ }^{a}$ ). Sentencia núm. 131/2012, de 15 de febrero. 
Audiencia Provincial de Alicante (Sección 5. ${ }^{\mathrm{a}}$ ). Sentencia núm. 104/2012, de 8 de marzo.

Audiencia Provincial de Jaén (Sección 2. ${ }^{\text {) }}$. Sentencia núm. 227/2012, de 25 de septiembre.

Audiencia Provincial de Madrid (Sección 19. ${ }^{a}$ ). Sentencia núm. 631/2012, de 19 de diciembre.

Audiencia Provincial de Murcia (Sección 5.․). Sentencia núm. 426/2012, de 27 de noviembre.

Audiencia Provincial de Madrid (Sección 14. ${ }^{\mathrm{a}}$ ). Sentencia núm. 368/2013, de 21 de octubre.

Tribunal Constitucional (Sala Primera). Sentencia núm. 289/1993, de 4 de octubre.

Tribunal Supremo (Sala de lo Civil). Sentencia núm. 208/1994, de 14 de marzo.

Tribunal Supremo (Sala de lo Civil). Sentencia núm. 331/1999, de 24 de abril.

Tribunal Supremo (Sala de lo Civil). Sentencia núm. 26/2000, de 20 de enero.

Tribunal Supremo (Sala de lo Civil). Sentencia núm. 465/2000, de 11 de mayo.

Tribunal Supremo (Sala de lo Civil, Sección Única). Sentencia n. ${ }^{\circ}$ 364/2003, de 10 de abril.

Tribunal Supremo (Sala de lo Civil, Sección 1. a). Sentencia núm. 220/2009, de 3 de abril.

Tribunal Supremo (Sala de lo Civil, Sección 1. a). Sentencia núm. 206/2011, de 22 de marzo.

Tribunal Supremo (Sala de lo Civil, Sección 1. a). Sentencia núm. 343/2012, de 30 de mayo.

Tribunal Supremo (Sala de lo Civil). Sentencia núm. 247/2013, de 22 de abril.

\section{Objeto del proceso}

Audiencia Provincial de Barcelona (Sección 13. ${ }^{a}$ ). Sentencia núm. $553 / 2008$, de 14 de octubre de 2008. 
Audiencia Provincial de las Islas Baleares (Sección 3. a). Sentencia núm. 300/2010, de 20 de junio de 2010.

Audiencia Provincial de Zaragoza (Sección 4. ${ }^{a}$ ). Sentencia núm. 489/2010, de 5 de noviembre de 2010.

Audiencia Provincial de Barcelona (Sección 13.a). Sentencia núm. 135/2011, de 28 de marzo de 2011.

Audiencia Provincial de Murcia (Sección 4. ${ }^{a}$ ), Sentencia núm. 575/2011, de 17 de noviembre de 2011.

Audiencia Provincial de La Coruña (Sección 3. ${ }^{a}$ ). Sentencia núm. 370/2012, de 10 de junio de 2012.

Audiencia Provincial de Valladolid (Sección 1. ${ }^{a}$ ). Sentencia núm. 267/2012, de 15 de junio de 2012.

Audiencia Provincial de Barcelona (Sección 4. ${ }^{a}$ ). Sentencia núm. 425/2012, de 19 de julio de 2012.

Audiencia Provincial de las Islas Baleares (Sección 5. ${ }^{a}$ ). Sentencia núm. 420/2012, de 4 de octubre de 2012.

Tribunal Supremo (Sala de lo Civil, Sección 1. a). Sentencia núm. 755/2008, de 24 de julio de 2008.

Tribunal Supremo (Sala de lo Civil, Sección 1. a). Sentencia 1219/2009, de 19 de diciembre de 2009.

Tribunal Supremo (Sala de lo Civil, Sección 1. ${ }^{\mathrm{a}}$ ). Sentencia, núm. 193/2009, de 26 de marzo de 2009.

Tribunal Supremo (Sala de lo Civil, Sección 1. ${ }^{a}$ ). Sentencia, núm. 684/2009, de 20 de octubre de 2009.

Tribunal Supremo (Sala de lo Civil, Sección 1. ${ }^{a}$ ). Sentencia núm. 137/2014, de 18 de marzo de 2014.

Tribunal Supremo (Sala de lo Civil, Sección 1.a). Sentencia núm. 180/2014, de 27 de marzo de 2014.

\section{Recursos}

Tribunal Constitucional (Sala Primera). Sentencia núm. 100/1993, de 22 de marzo (BOE núm. 100 de 27 de abril de 1993). Recurso de Amparo 690-1990.

Tribunal Constitucional (Sala Primera). Sentencia núm. 344/1993, de 22 de noviembre (BOE núm. 311 de 29 de diciembre de 1993). Recurso de Amparo 872-1991. 
Tribunal Constitucional (Sala Primera). Sentencia núm. 346/1993, de 22 de noviembre (BOE núm. 311 de 29 de diciembre de 1993). Recurso de Amparo 1661-1991.

Tribunal Supremo (Sala Primera, Sección 1. ${ }^{a}$ ). Sentencia núm. 2059/2006, de 30 de noviembre de 2011.

Tribunal Supremo (Sala Primera). Sentencia núm. 84/2013, de 26 de febrero.

\section{Régimen de notificaciones}

Tribunal Constitucional (Sala Segunda). Sentencia núm. 40/2005, de 28 de febrero (BOE núm. 81 de 5 de abril de 2005). Recurso de Amparo 1923-2002.

Tribunal Constitucional (Sala Primera). Sentencia núm. 293/2005, de 21 de noviembre (BOE núm. 304 de 21 de diciembre de 2005). Recurso de Amparo 6834-2000.

Tribunal Constitucional (Sala Primera). Sentencia núm. 306/2006, de 23 de octubre (BOE núm. 284 de 28 de noviembre de 2006). Recurso de Amparo 7855-2003.

Tribunal Constitucional (Sala Primera). Sentencia núm. 163/2007, de 2 de julio (BOE núm. 185 de 3 de agosto de 2007). Recurso de Amparo 1356-2005.

Tribunal Constitucional (Sala Primera). Sentencia núm. 78/2008, de 7 de julio (BOE núm. 178 de 24 de julio de 2008). Recurso de Amparo 5258-2005.

Tribunal Constitucional (Sala Primera). Sentencia núm. 176/2009, de 16 de julio (BOE núm. 193 de 11 de agosto de 2009). Recurso de Amparo 3321-2005.

Tribunal Constitucional (Sala Segunda). Sentencia núm. 30/2014, de 24 de febrero (BOE núm. 73 de 25 de marzo de 2014). 
